\title{
MODELLING REGIONAL HOUSING PRICES IN SPAIN
}

Laura Alvarez Román

and Miguel Garcia-Posada Gomez.

Documentos de Trabajo

N. 1941

\section{BANCODEESPAÑA}

Eurosistema

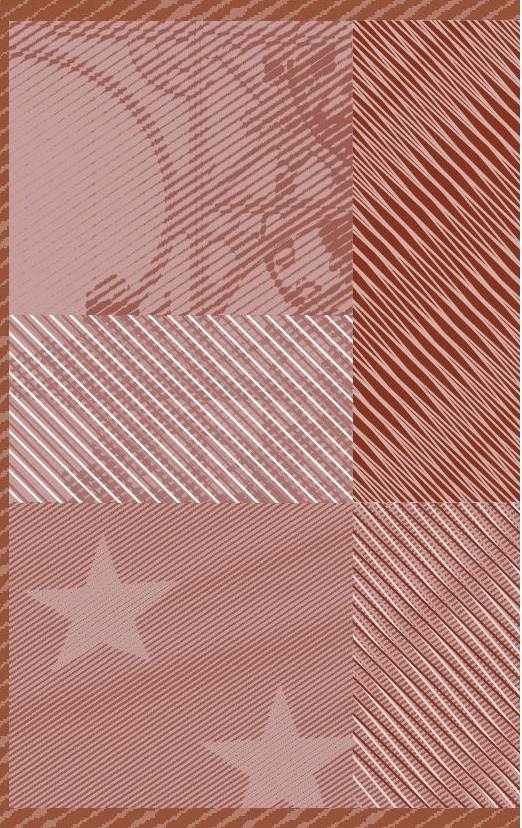


MODELLING REGIONAL HOUSING PRICES IN SPAIN

Laura Álvarez Román and Miguel García-Posada Gómez ${ }^{(*)}$

BANCO DE ESPAÑA

(*) Corresponding author: Miguel García-Posada Gómez. Email: miguel.garcia-posada@bde.es. Address: Banco de España, C/ Alcalá 48, 28014 Madrid, Spain. The views expressed in this paper are those of the authors and do not necessarily coincide with those of Banco de España and the Eurosystem. We would like to thank Oscar Arce, Roberto Blanco, Ángel Gavilán, Sergio Mayordomo, Carlos Thomas, an anonymous referee and seminar participants at Banco de España for their useful comments and suggestions. We are particularly grateful to Sociedad de Tasación for sharing their data on house prices and answering all our queries about it.

Documentos de Trabajo. N. ${ }^{\circ} 1941$

2019 
The Working Paper Series seeks to disseminate original research in economics and finance. All papers have been anonymously refereed. By publishing these papers, the Banco de España aims to contribute to economic analysis and, in particular, to knowledge of the Spanish economy and its international environment.

The opinions and analyses in the Working Paper Series are the responsibility of the authors and, therefore, do not necessarily coincide with those of the Banco de España or the Eurosystem.

The Banco de España disseminates its main reports and most of its publications via the Internet at the following website: http://www.bde.es.

Reproduction for educational and non-commercial purposes is permitted provided that the source is acknowledged.

(C) BANCO DE ESPAÑA, Madrid, 2019

ISSN: 1579-8666 (on line) 
Abstract

We estimate the long-run relationship between real housing prices of new dwellings and their fundamentals in a panel of the 50 Spanish provinces between 1985 and 2018. We find a cointegrating relationship between real house prices and per capita real income, unemployment rate and demographic density. According to our estimates, house prices were above their long-run equilibrium values in most provinces in 2007, during the peak of the previous boom, but there was substantial heterogeneity in the size of this gap. At the end of 2018 house prices were slightly below their estimated long-run equilibrium values in most provinces, but a few of them exhibited moderate positive deviations from those levels. Our results highlight the importance of modelling house prices at the regional level, as aggregate results may hide important heterogeneous developments.

Keywords: house prices, fundamentals, cointegration, regional analysis.

JEL classification: R30, R31, R32. 


\section{Resumen}

En el presente trabajo estimamos la relación a largo plazo entre los precios de la vivienda nueva reales y sus fundamentales en un panel de 50 provincias españolas entre 1985 y 2018. Encontramos una relación de cointegración entre los precios de vivienda reales y la renta real per cápita, la tasa de paro y la densidad demográfica. De acuerdo con nuestras estimaciones, los precios de la vivienda estaban por encima de sus valores de equilibrio a largo plazo en la mayoría de las provincias en 2007, en el punto máximo de la anterior expansión, pero había una elevada heterogeneidad en la magnitud de estas diferencias. A finales de 2018, los precios de la vivienda estaban ligeramente por debajo de su nivel de equilibrio estimado de largo plazo en la mayoría de las provincias, mientras que en otras el valor de estos activos inmobiliarios superaba, aunque muy moderadamente, dicho nivel de largo plazo. Nuestros resultados muestran la importancia de modelizar los precios de la vivienda a escala regional, puesto que los resultados agregados pueden encubrir importantes evoluciones heterogéneas.

Palabras clave: precios de la vivienda, fundamentales, cointegración, análisis regional.

Códigos JEL: R30, R31, R32. 


\section{Introduction}

The ongoing recovery of house prices in Spain after the collapse of the housing bubble in 2008, and its dire consequences on the real economy and the banking sector, has renewed the interest of academics and policy makers on assessing whether real housing prices are currently aligned with their long-run fundamentals.

The usual approach to perform such an analysis is to model aggregate house price indices at the national level and their relationship with structural determinants such as income, interest rates, housing stock and housing loans [e.g. Martínez-Pagés and Maza (2003), Gimeno and Martínez-Carrascal (2010)]. This methodology can be useful to detect large deviations from long-run equilibrium prices that are widespread at the national level.

However, that approach implicitly assumes a single housing market in Spain. This assumption may not be warranted because housing is a highly differentiated good, especially in the spatial dimension. High regional heterogeneity could imply that housing prices may be above the long-run equilibrium values in some regions, while other regions could still experience a correction from the previous boom. Therefore, we must analyse several housing markets, located at the regional or even local level.

One additional potential benefit of a local analysis is that the use of regional data enables a better estimation of the parameters of interest, especially of the long-run relationship between housing prices and their determinants, by exploiting crosssection variability. For instance, using time series data from Spain, Martínez-Pagés and Maza (2003) face a multicollinearity problem between income and interest rates as the former increased steadily, while the latter decreased gradually during the sample period. In our case, exploiting the heterogeneity of per capita income across provinces allows us to circumvent that problem.

Our goal is to analyse the degree of deviation from long-run equilibrium prices in housing markets at the province and national level in Spain. To do so, we use a long panel (1985-2018) of housing prices for the 50 Spanish provinces. Our methodology relies on panel data cointegration techniques, as real housing prices should have a long-run relationship with their determinants (income, unemployment, population 
density, etc.). In addition, we include province fixed effects to control for timeinvariant characteristics such as climate, location and culture.

Our main findings indicate that in most Spanish provinces real housing prices were above the values implied by their fundamentals in 2007, the peak of the boom. However, there was substantial regional heterogeneity, as the upward deviation ranged between $6 \%$ and $58 \%$ according to our baseline estimates. By contrast, at the end of 2018, in most provinces real housing prices were slightly below the estimated long-run equilibrium values implied by their fundamentals. Nevertheless, the prices in a few provinces exhibited a positive deviation from those values, with a regional maximum of $13 \%$. We also aggregate our results at the national level, by constructing weighted averages of the regional series. According to our estimates, the highest upward deviation from fundamentals took place in 2007, and amounted to $28 \%$. By contrast, at the end of 2018 national prices were, on average, $11 \%$ below their estimated long-run equilibrium values.

Two words of caution are in order here. First, our sample only comprises data on new houses. This may limit the external validity of our results if the price dynamics of new and second-hand houses differ substantially, especially in the recent period given the low number of transactions of new houses. ${ }^{1}$ Second, as our analysis is performed at the province level it may hide deviations from long-run equilibrium values that take place at a local level, such as cities or districts. López-Rodríguez and Llanos (2019) evidenced that the rental housing market in Spain, more dynamic than the sales market over the last few years, has experienced significant and heterogeneous increases in prices, even at the intra-city level. As a result of demand concentration and rigid housing supply in the short term, house affordability constrains might arise, especially for the most vulnerable segments of the population. In this regard, our analysis should not be considered as a measure of housing affordability, as price alignment with fundamentals might hide high priceto-income ratios in certain areas, but rather an approximate indication of the housing market stance at the regional level.

\footnotetext{
${ }^{1}$ On average, free new houses represented 10\% of total house transactions over the period 2014 2018. By contrast, at the peak of the boom they accounted for almost $50 \%$ of total transactions. Source: Ministry of Public Works and Infrastructure.
} 
In addition, we also construct an error correction model to analyse the short-run dynamics of real house prices. Two parsimonious models provide a good fit for the growth rate of real housing prices at the regional level, as the correlation between observed and predicted average growth rate of real housing prices ranges between 0.87 and 0.89 . The average speed of adjustment is moderate, as we obtain that between $6.8 \%$ and $8.5 \%$ of the disequilibrium at $\mathrm{t}-1$ is removed in period $\mathrm{t}$. Therefore, in our sample the average half-life of a shock is between 4 and 5 years. However, there is substantial heterogeneity across provinces.

Ours is not the first paper that uses regional data to model housing prices. For instance, Holly et al (2010) exploit US state-level panel data from 1975 to 2003. They take explicit account of both cross-sectional dependence among US states and parameter heterogeneity. They find a cointegrating relationship between real house prices and real per capita income with coefficients $(1,-1)$, as predicted by their theoretical model. ${ }^{2}$ Álvarez-Lois and Nuño-Barrau (2007) use panel data for the 50 Spanish provinces between 1995 and 2006. ${ }^{3}$ The fundamentals that enter the cointegrating relationship (income, housing stock and real interest rate) are derived from a DSGE model. Our main contribution with respect to that paper is the use of a much longer panel, from 1985 to 2018, which comprises two complete business cycles, including the collapse of the housing market between 2008 and 2013 and its gradual recovery since 2014.

The rest of the paper is structured as follows. Section 2 explains the selection of dependent and explanatory variables. Section 3 provides descriptive evidence of the variables. Section 4 describes the methodology, the main empirical analyses and the results obtained. Section 5 presents a robustness analysis with an alternative model. Finally, section 6 concludes.

\section{Dependent and explanatory variables}

The dependent variable in our analysis is real housing prices. We need to take into consideration that multiple methodological issues arise when computing housing

\footnotetext{
${ }^{2}$ Other papers that exploit US regional data to test for a cointegrating relationship between house prices and income are Malpezzi (1999), Capozza et al (2002) and Gallin (2006).

${ }^{3}$ Another paper that exploits regional data of Spain, but at the level of Comunidad Autónoma, is García-Montalvo (2001).
} 
price series. First, price sources can range from appraisals to transaction prices. Second, houses are vastly heterogeneous across time and space so price series must be adjusted for compositional sample changes. However, there is not a unique method to perform such adjustment (Eurostat, 2013). Therefore, different sources and methodologies can result in slightly different housing price series.

In our analysis, we use housing prices from a private source, the company Sociedad de Tasación (SdT). We construct a balanced panel of the real housing prices of the 50 Spanish provinces between 1985 and 2018 at semi-annual frequency. We choose this dataset because it has the longest time horizon among the available regional house price series in Spain, covering two complete business cycles. ${ }^{4}$ In this database prices are negotiated offer prices obtained through a fieldwork in which SdT agents visit or contact promotions pretending to be a buyer. As a result, housing prices are closer to transaction prices than appraisals or pure offer prices. The sample only includes non-protected new houses. Compositional sample changes are circumvented through stratification methods. More details about the construction of the real housing price series can be found in the data appendix.

Regarding the explanatory variables, to conduct our analysis we need to consider the main structural determinants of house prices, i.e., those variables that exhibit a long-run relationship with real housing prices. Previous literature has found that per capita income is the most important structural determinant of house prices. For instance, Holly et al (2010) find that real housing prices and real per capita income are cointegrated with coefficients $(1,-1)$. However, aggregate income may be an incomplete determinant of long-run housing prices if income is unevenly distributed across households, a fact that tends to be amplified during crisis periods. According to Anghel et al. (2018), $78 \%$ of the households in the first $20^{\text {th }}$ percentile of income in Spain had a home ownership in 2008. In 2014 this percentage was reduced to $67 \%$, while in the $90^{\text {th }}$ percentile this percentage only fell by 3 pp, evidencing a lower acquisition of dwellings by the lower income segment during the crisis.

\footnotetext{
${ }^{4}$ The housing price series of INE starts in 2007, and it is only disaggregated at the level of Comunidad Autónoma (in Spain each Comunidad Autónoma comprises one or more provinces). The price series of the Ministry of Public Works and Infrastructure is disaggregated at the province level, but it starts in 1995. It is worth noting that the housing price series of SdT exhibit a smoother behaviour than those of the National Statistics Institute (INE). For example, during the 2014-2018 period nominal house prices in the province of Madrid grew 43\% according to INE vs 20\% according to SdT.
} 
As an alternative measure of economic development, we also consider the unemployment rate, as in Bundesbank (2013). As Gan et al. (2018) point out, housing demand is lower in regions with higher unemployment due, among other factors, to tighter credit conditions and job insecurity. In Spain this is particularly important as southern provinces systematically present higher unemployment rates than northern provinces due to structural factors such as different productive structures or unemployment protection,

Previous literature has widely regarded interest rates as key determinants of real housing prices [see, for the Spanish case, Gimeno and Martínez-Carrascal (2010), Álvarez-Lois and Nuño-Barrau (2007) and Martínez-Pagés and Maza (2003)]. The reason is that the housing market is characterised by the need of most households to subscribe a mortgage due to the large value of dwellings relative to household income. Therefore, the mortgage financing conditions play a crucial role in the demand for dwellings. We account for the debt servicing cost in the housing market by using the national nominal mortgage interest rate. ${ }^{5}$ The choice of the nominal interest rate is motivated by the so-called "tilt effect" (Lessard and Modigliani, 1975). For instance, Nickell (2002) shows how a decrease in inflation and nominal interest rates, keeping the real interest rate constant, reduces the debt service payments of a loan during its early years, which allows a higher indebtedness of the potential borrowers. This may especially important in the case of Spain, given the large decrease in nominal interest rates and inflation since the mid-80s.

In addition to account for the price of credit through nominal interest rates, we also account for its quantity by considering a measure of leverage at the regional level. In particular, we compute the ratio of housing credit to gross disposable income, in line with the findings of Gimeno and Martínez-Carrascal (2010), who find a long-run relationship between house prices and house purchase loans.

Another evident long-term determinant of housing prices is the housing supply, which may be captured by per capita housing stock [e.g. Álvarez-Lois and NuñoBarrau (2007) and Martínez-Pagés and Maza (2003)]. Housing supply is inelastic in the short-run because of the long production process of dwellings and the limited supply of land, especially in certain locations. We may therefore treat the supply of

\footnotetext{
${ }^{5}$ Real interest rates, constructed with nominal interest rates and the $\mathrm{CPI}$, yield very similar results.
} 
houses as given in the short run. Another fundamental factor on the supply side is the real cost of construction, so we include an index of costs in the construction sector, as in García-Montalvo (2001), deflated by the province CPI. This factor is especially important in our analysis, since our data are based on new dwellings.

Finally, demographic factors may influence the demand for dwellings in the long run [Bundesbank, (2013)]. As the population in Spain is unevenly distributed across the country, we account for different demographic pressures in the housing market through population density. We also consider the fraction of population between 30 and 54 years as a measure of potential house buyers, which account for recently created new households. ${ }^{6}$

\section{Descriptive evidence}

Before carrying out the econometric analysis, we inspect the series to detect patterns in the data. Figure 1 shows the evolution of nominal housing prices in Spain, both the national average and the series for Madrid and Barcelona, two of the richest provinces. As a benchmark, Figure 1 also plots the series of housing prices according to the Ministry of Public Works and Infrastructure at the national level.

We can observe the strong housing boom between 2000 and 2007, the subsequent bust between 2008 and 2013 and the mild recovery between 2014 and 2018, where nominal house prices grew an $11 \%$ in cumulative terms. However, the national average hides substantial heterogeneity as house prices in provinces as Madrid or Barcelona grew 20\% during the same period. ${ }^{7}$ In real terms, national housing prices in the second semester of 2018 were $34 \%$ below its historical maximum in 2007, and ranged from Zaragoza, which real house prices were $46 \%$ percent below, to Lugo and Ourense, where real house prices were around $77 \%$ of pre-crisis levels.

\footnotetext{
${ }^{6}$ We follow Bundesbank (2013) for the choice of the age range, where they consider that dwellings are typically acquired in the 30-55 age cohort.

${ }^{7}$ Heterogeneity is also present within provinces: Madrid and Barcelona municipality's nominal house prices grew a $28 \%$ and $34 \%$, respectively, from $2014 \mathrm{~h} 2$ to $2018 \mathrm{~h} 2$.
} 
We also observe that the house price series for the national average, Madrid and Barcelona are highly correlated. In general, the series of housing prices for the 50 provinces are very synchronic. In other words, there is substantial cross-section correlation in the data. This feature of the data determines the choice of the econometric techniques, as explained in section 4.

Nevertheless, the period of recovery initiated in 2014, is different from the long period of expansion between 1995 and 2007, as we can see in Figures 2 and 3. Figure 2 shows that the strong growth in housing prices was widespread during the run-up to the crisis. By contrast, Figure 3 shows that significant price growth between 2014 and 2018 was only been observed in a few provinces such as Madrid, Barcelona and Balearic Islands, while price declines were registered in many other provinces. This regional heterogeneity is also observed in the number of transactions, which are still far from pre-crisis levels, especially in the new dwellings sector (Banco de España, 2019). However, we cannot discard the possibility that increases in housing prices in a certain province spread to other areas over time. As a result, the assessment of deviations from fundamentals in housing prices at the regional level is important for both the region itself and as an early signal of warning before being noticeable at a more aggregated level.

For the explanatory variables and for exhibition purposes, we compute their average across the 50 Spanish provinces. The temporal evolution of these averages is displayed in the data appendix. On the demand side, real income per capita grew steadily from the mid 80's until falling substantially with the global financial crisis, and it has bounced back since 2014. The unemployment rate has followed closely the country's business cycle. The nominal mortgage interest rate has decreased dramatically from values around 15\% during the 80's and early 90's to values around $2 \%$ in 2018. The percentage of population between 30 and 54 years increased steadily until 2013, and it has declined since then. The average housing credit to income ratio grew exponentially between 1985 and 2007 and it has decreased since then due to the deleveraging process of Spanish households and a more prudent credit policy.

On the supply side, the per capita housing stock has grown steadily since the mid 80 's because, although the construction of houses declined severely during the 
crisis, population decreased due to the return of migrants to their home countries while still remains unsold housing stock from the pre-crisis period. Real construction costs decreased substantially between 1985 and 2003, bounced back between 2003 and 2010 and declined again from 2010. However, in 2018 real construction costs exhibit positive annual growth rates partly driven by increasing labour costs in the sector.

A first look at the data reveals considerable heterogeneity in the relationship between real housing prices and their fundamentals. Figure 4 displays price-toincome ratios for the 50 provinces at the peak of the boom (2007h1) and at the end of 2018. Price-to-income ratios are computed as the average housing price of the province $(€ / \mathrm{m} 2)$ divided by per capita income. This descriptive evidence suggests that there was substantial heterogeneity across provinces Also notice that price-toincome ratios were systematically higher at the peak of the boom than at the end of 2018, suggesting a significant correction in the market. However, analysis at the province level might hide recent heterogeneous market developments at a more local level.

In order to correct for right skewness, we take the natural logarithm of the following variables: real housing price, per capita real income, per capita housing stock and population density. The definitions of the variables, together with their data sources, are displayed in Table 1.

\section{Empirical analysis}

\subsection{Cross-section dependence tests}

We begin our empirical analysis by testing the presence of cross-section dependence. Cross-section correlation means that variables are correlated across different units, provinces in our case. A source of cross-section dependence is spatial dependence and local spillovers. For instance, as the price of housing increases in Madrid, people move to adjacent provinces, raising the demand for dwellings in those areas and therefore increasing housing prices. Another source of cross-section dependence is common shocks (e.g. oil prices and technological change). The implications of cross-section dependence are twofold. First, 
estimators are inefficient and standard errors are biased. Second, estimators may be inconsistent if unobserved common factors are correlated with regressors.

We test cross-section dependence with the CD test developed by Pesaran (2004). We implement the test in three steps. First, we run Augmented Dickey-Fuller (ADF) regressions for each variable and each cross-section separately in order to remove any unit root in the variables, and save the residuals. Second, we compute pairwise correlations of the residuals: for instance, the correlation of those residuals between Madrid and Barcelona. Third, we run the CD test of Pesaran (2004), where the null hypothesis is cross section independence, defined as

$$
C D=\sqrt{\frac{2 T}{N(N-1)}}\left(\sum_{i=1}^{N-1} \sum_{j=i+1}^{N} \hat{\rho}_{i j}\right) \sim N(0,1)
$$

where $\hat{\rho}_{i j}$ are the pairwise correlations of the residuals

$$
\hat{\rho}_{i j}=\hat{\rho}_{j i}=\frac{\sum_{t=1}^{T} \hat{u}_{i t} \hat{u}_{j t}}{\sqrt{\sum_{t=1}^{T} \hat{u}_{i t}^{2}} \cdot \sqrt{\sum_{t=1}^{T} \hat{u}_{j t}^{2}}}
$$

Table 2 displays CD tests and average cross-correlation coefficients computed with the residuals of ADF (with 4 lags) regressions for each variable and each crosssection separately. These tests provide strong evidence on cross-section correlation, as we reject the null hypothesis of cross-section independence in all variables. Results are very similar when computing the residuals form ADF regressions with 1, 2 or 3 lags.

\subsection{Unit root tests}

The next step is to check whether the variables are integrated of order one. Due to the existence of cross-section dependence, we cannot use conventional unit root tests for panels such as the IPS test (Im et al. 2003). Instead, we use the CIPS test proposed by Pesaran (2007). The key idea of this test is to filter out cross-sectional dependence by augmenting the ADF regressions with cross-section averages. The 
CIPS test is based on cross-section augmented ADF (CADF) regressions, carried out separately for each province, namely:

$$
\Delta \omega_{i t}=a_{i 0}+a_{i 1} t+a_{i 2} \omega_{i, t-1}+a_{i 3} \bar{\omega}_{t-1}+\sum_{j=0}^{p} d_{i j} \Delta \bar{\omega}_{t-j}+\sum_{j=1}^{p} \delta_{i j} \Delta \omega_{i, t-j}+v_{i t}
$$

where $\bar{\omega}_{t}=\frac{1}{N} \sum_{i=1}^{N} \omega_{i, t}$ denotes the cross-section mean of $\omega_{i, t}$. The CIPS statistic is a simple cross-section average of $\tilde{t}_{l}$ defined by:

$$
\text { CIPS }=\frac{1}{N} \sum_{i=1}^{N} \widetilde{t_{i}}
$$

where $\tilde{t}_{i}$ is the OLS t-ratio of $a_{i 2}$ in the above CADF regression. In this test, the null hypothesis establishes that the variable is integrated of order 1 in all units, where the alternative hypothesis establishes that the variable is stationary in some units.

Results are displayed in Table 3. For robustness, we report results from CADF tests of order 1, 2, 3 and 4. In the case of the nominal mortgage interest rate, as there is no cross-section variation (there is only the national interest rate for the 50 Spanish provinces), we report Augmented Dickey Fuller (ADF) tests.

Table 3 shows that we cannot reject the presence of a unit root in all provinces for the variables per capita income, population density, nominal interest rate, proportion of population between 30 and 54 years of age, housing credit to income and real construction costs. The same occurs for unemployment rate if the order of the ADF test is 3 or $4 .{ }^{8}$ We also test for the presence of a second unit root by applying those tests to the first difference of the variables, but we reject the null hypothesis in all cases, which means that the variables are integrated of order 1.

By contrast, we reject the presence of a unit root in all provinces in the case of real housing price and per capita housing stock. Therefore, the series are stationary in some provinces. To complement this evidence, we also run Dickey-Fuller and Phillips-Perron tests for each province separately for these two variables. ${ }^{9}$ According to those tests, we cannot reject the presence of a unit root in most

\footnotetext{
${ }^{8}$ Visual inspection of the series (see Data Appendix) reveals that those variables do not have a constant mean and a constant variance, which means that they are not stationary.

${ }^{9}$ Those results are available upon request.
} 
provinces. We also estimate AR (1) models for each province, and we find very high autoregressive coefficients, close to 1 , which reveal a high level of persistence. These findings, together with the results of previous literature, suggest that real housing prices and per capita housing stock are integrated of order 1 , as we shall assume for the rest of the paper.

\subsection{Cointegrating vectors and cointegration tests}

In order to establish a long-run relationship between real housing prices and their fundamentals we estimate a fixed effects model by Within Group:

$y_{i t}=\alpha_{i}+\beta^{\prime} x_{i t}+\varepsilon_{i t}$

Fixed effects may capture time-invariant factors such as climate, culture and location of each province. As some constant province factors, such as being a coastal province with higher foreign demand for dwellings or being a capital, are potentially relevant to determine housing prices, we consider relevant to include fixed effects in our analysis. ${ }^{10}$ As long as there is cointegration, the fitted values of (5) show the equilibrium long-run housing prices. Cointegration is tested by ascertain whether the residuals of the regression are stationary.

Notice that in equation (5) the long-run coefficients are the same for all provinces. The reason for assuming a homogeneous long-run equilibrium relationship is that the underlying economic principles that are employed to establish the equilibrium and derive the theoretical foundations should apply similarly in all provinces, whereas the short-run adjustment process (as captured by the error correction model) may differ across provinces due to cultural and institutional features (ÁlvarezLois and Nuño-Barrau, 2007). ${ }^{11}$

In order to select the key drivers of real housing prices, we follow a general-tospecific methodology: we first include all regressors and drop those with

\footnotetext{
${ }^{10}$ We have also implemented a poolability test, i.e., an F-test whose null hypothesis is that all fixed effects are jointly equal to zero. The reported $p$-value is zero, implying that we reject the null hypothesis for any significance level.

11 Pesaran (1997, page 188) states: "In cases where the theory predicts the same long-run relationship across groups, but does not necessarily require the short-run adjustments to equilibrium to be the same, it would be possible to take advantage of the extra power that pooling provides without introducing inconsistencies that arise when heterogeneity of short-run dynamics across groups is ignored".
} 
insignificant coefficients. However, to implement that methodology we cannot use (5) because the usual inference procedures do not apply. In particular, because the regressors are I (1), OLS and Within Group are not asymptotically normally distributed, and the t-statistics do not necessarily have an approximate t-distribution (Wooldridge, 2003).

This problem can be fixed by including leads, lags and contemporaneous changes of the regressors, as implemented by the leads and lags estimator of Stock and Watson (1993) in the context of time series or by Dynamic OLS (DOLS) of Kao and Chiang (2000) in panel data. Therefore, to carry out the general-to-specific methodology we estimate the following regression:

$y_{i t}=\alpha_{i}+\beta^{\prime} x_{i t}+\sum_{k=-q}^{q} \gamma_{i k}^{\prime} \Delta x_{i, t+k}+\varepsilon_{i t}$

We set $\mathrm{q}=2$ (two lags and two leads of $\Delta x_{s}$, and contemporaneous changes $\Delta x_{t}$ ). By doing so, we obtain an asymptotically normal $t$ statistic. In addition, we use Discroll-Kraay standard errors, which are robust to serial correlation and crosssection correlation. We find that per capita income, unemployment rate and population density are significant determinants of real housing prices in Spain (Table 4). The coefficients also have the expected sign: higher income, lower unemployment and higher population density put upward pressure on real housing prices. In particular, according to the model, the price-income elasticity is 0.63 . This figure is quite low in comparison with the estimations of other studies with Spanish data. $^{12}$

To conclude that this a valid cointegration relationship we check the stationary of the residuals. As the CD test on the residuals indicate substantial cross-section correlation (see bottom of Table 4), we follow Holly et al. (2010) and test whether the residuals are I (0) with the CIPS test. The results, displayed in Table 5, show that we reject the null hypothesis that all series are integrated of order 1. As before, we complement those results with Dickey-Fuller and Phillips-Perron tests for each individual series. For most provinces, we reject the null hypothesis that the residuals have a unit root.

\footnotetext{
${ }^{12}$ Martínez-Pagés and Maza (2003) find that the price-income elasticity is 2.8, while Gimeno and Martínez-Carrascal estimate 1.7 and Álvarez-Lois and Nuño-Barrau (2007) find an elasticity of 1.4.
} 


\subsection{Main empirical results: real housing prices and deviations from long-run equilibrium values.}

In this section, we assess the degree of deviation from the long-run equilibrium value in the regional housing markets, as well as at the national level. We obtain the longrun equilibrium housing prices as a linear combination of the fixed effects and the product of the betas and the value of the regressors. We define the degree of deviation from fundamentals as the difference between observed real housing prices and long-run equilibrium real housing prices.

Figure 5 shows the distribution over time of the housing price deviation from the long-run equilibrium values across the 50 Spanish provinces, as well as its dispersion over time. In particular, it shows the range between the minimum and the maximum, the range between the $25^{\text {th }}$ and $75^{\text {th }}$ percentile and the median. This figure evidences the different housing cycles of the Spanish economy in the last three decades. At the peak of the 2000's housing boom, the first semester of 2007 , housing prices in all Spanish provinces were above their long-run equilibrium values. The dispersion was considerable, with some provinces exhibiting small deviations and other provinces exceeding a 50\% deviation. The median deviation was $27 \%$. By contrast, at the end of 2018, we can observe that, in most provinces, real housing prices were slightly below the values implied by their fundamentals. The median deviation was $-12 \%$.

We also assess the evolution of deviations from the long-run equilibrium value at the national level. In order to do so, we compute the national observed real housing price level and the national long-run equilibrium real housing price level by means of population-weighted averages of each province series. Results are displayed in Figure 6. According to the figure, real housing prices were below their long-run equilibrium value during the second half of the 1990's and beginning of the 2000's and above them during the housing boom of the 2000's. In particular, the maximum deviation of average national prices was $28 \%$ in the first semester of 2007 . This result is line with that of IMF (2008), which estimates a house price gap of about $20 \%$ in 2007 . By contrast, average national real housing prices were $11 \%$ below their long-run equilibrium values at the end of $2018^{13}$.

\footnotetext{
${ }^{13}$ Our aggregate results are in line with those of Banco de España using an error correction model with National Statistics Institute data (Banco de España, 2019).
} 
The previous approach models the long-run equilibrium price as a linear combination of the explanatory variables, where the coefficients are derived from the cointegrating vector. Therefore, this analysis implicitly assumes that the explanatory variables are at their long-run equilibrium values. However, this may not always be the case. For instance, the unemployment rate may be above its longrun equilibrium level during a recession. Therefore, as a robustness exercise, we first apply the Hodrick-Prescott filter to the dependent and explanatory variables to keep the trend part of the series, and then we re-estimate the cointegrating vector. The results at the national level, summarised in Figure 7, are very similar to the baseline results, but, as expected, the average long-run equilibrium price is substantially smoother.

Finally, we have computed the contribution of each explanatory factor to the house price growth during the recovery period (2013h2-2018h2) as a linear combination of the cointegrating coefficient and the growth of each variable at the province level. We observe that the main driver pushing housing prices upwards is the decrease in the unemployment rate, followed by the increase in real gross disposable income. On average, the effect of population growth is slightly negative, but presents a substantial heterogeneity across provinces. In particular, insular provinces and provinces with large cities (e.g. Madrid, Barcelona) exhibited a positive contribution of population growth on house price growth. Nevertheless, unexplained factors accounted for negative contributions in most provinces.

\subsection{Modelling short-run price dynamics}

In addition to determine whether real housing prices are deviated from the price determined by their fundamentals, we are interested on evaluating the speed at which real housing prices converge to their equilibrium values, as more flexible markets may adjust more quickly to deviations from their steady state equilibrium.

In order to do so, we estimate the short-run dynamics of real housing prices via a panel error correction model (ECM). Besides, we evaluate whether convergence speed depends on the province. We estimate the ECM with two different estimators. 
First, we can estimate the ECM via dynamic fixed effects. In this estimator, all parameters, except intercepts, are constrained to be equal across panels:

$\Delta y_{i t}=\alpha_{i}+\varphi\left(y_{i t-1}-\beta^{\prime} x_{i t-1}\right)+\theta \Delta y_{i t-1}+\gamma \Delta x_{1, t}+\delta \Delta x_{1, t-1}+\cdots+\varepsilon_{i t}$

Second, we can estimate the ECM via the pooled mean-group (Pesaran et al, 1999). In this estimator, long-run effects, betas, are constrained to be equal across all panels, but the short-run coefficients, including $\varphi$, the speed of adjustment, are allowed to differ across panels:

$\Delta y_{i t}=\alpha_{i}+\varphi_{i}\left(y_{i t-1}-\beta^{\prime} x_{i t-1}\right)+\theta_{i} \Delta y_{i t-1}+\gamma_{i} \Delta x_{1, t}+\delta_{i} \Delta x_{1, t-1}+\cdots+\varepsilon_{i t}$

For the pooled mean-group, we report the cross-section average of the individual coefficients. In both cases, we follow the Engle-Granger two-step procedure, and replace $\left(y_{i t-1}-\beta^{\prime} x_{i t-1}\right)$ with the residuals $\hat{\varepsilon}_{i t-1}$ that arise from the estimation of the cointegration vector.

The estimations of both models are presented in Table 6 . The coefficients on the error correction term, the speed of adjustment, imply that between $6.8 \%$ and $8.5 \%$ of the disequilibrium at $\mathrm{t}-1$ is removed in period $t$. These estimates are substantially smaller than the speed of adjustment estimated by Álvarez-Lois and Nuño-Barrau (2007). The half-life of a shock to housing prices is approximately- $\ln (2) / \ln (1+\varphi)$, where $\varphi$ is the speed of adjustment, which implies that the half-life ranges between 4 and 5 years. Regarding the rest of variables, their coefficients have the expected sign when they are significant: income growth and population growth have a positive effect on the growth of housing prices, while increases in the unemployment rate have a negative impact.

The estimation of the ECM by pooled mean-group also allows us to estimate the speed of adjustment for each province. These estimates are presented in Table 7. There is substantial heterogeneity across provinces, but we do not observe any clear pattern. For instance, the speed of adjustment of Madrid (4.3\%) is one of the lowest, while the speed of adjustment of Barcelona (10.6\%) is one of the highest.

Both models provide a good fit for the growth of real housing prices at the national level. Figure 8 shows the means of observed and predicted average growth of real housing prices, estimated by Dynamic Fixed Effects. The correlation between the two series is 0.87 . Similarly, Figure 9 displays the means of observed and predicted 
average growth of real housing prices estimated by Mean Group. The correlation between the two series is 0.89 .

\section{Robustness analysis: alternative model}

In the baseline analyses we include province fixed effects and estimate the model by Within Group. We consider that, given the existence of time-invariant determinants of housing prices such as culture, location and climate in the different provinces of Spain, we should control for them via fixed effects. However, as a robustness check, we exclude province fixed effects from our estimation to evaluate whether the equilibrium real housing prices change.

We again carry out a general-to-specific methodology to select the determinants of real housing prices. In particular, we estimate the following regression:

$y_{i t}=\alpha+\beta^{\prime} x_{i t}+\sum_{k=-q}^{q} \gamma_{i k}^{\prime} \Delta x_{i, t+k}+\varepsilon_{i t}$

We set $\mathrm{q}=2$ (two lags and two leads of $\Delta x_{s}$, and contemporaneous changes $\Delta x_{t}$ ). By doing so, we obtain an asymptotically normal $t$ statistic. We estimate (9) by pooled OLS.

We find five determinants of real housing prices: per capita real income, unemployment rate, population density, nominal interest rates and per capita housing stock. Results are very similar when replacing nominal interest rates with real interest rates, computed using province CPIs.

The estimation of the cointegration vector is displayed in Table 8. The main difference with the baseline model is the inclusion of the interest rate and housing stock as significant explanatory variables. The coefficients of those variables have the expected sign. In particular, a decrease in housing stock and interest rates puts upward pressure on housing prices. Table 9 confirms the presence of cointegration, as unit root tests on the residuals reject the null hypothesis of integration.

We can also use this alternative cointegration vector to assess the degree of deviation of prices from long-run equilibrium values in the regional housing markets, as well as at the national level. According to Figure 10, most provinces housing prices were above their long-run equilibrium levels at the peak of the 2000's housing 
boom. The maximum deviation exceeded $70 \%$, while the median deviation was $21 \%$. Nevertheless, a few provinces exhibited a slight negative deviation (with a regional minimum of $-5 \%$ ). According to the same figure, in most provinces, real housing prices were somewhat below their long-run equilibrium value at the end of 2018, while there was some positive deviation (with a regional maximum of $13 \%$ ) in several provinces.

The general picture at the national level is also quite similar to the one obtained with the baseline model, as we can observe in Figure 11. According to the figure, prices were below their long-run equilibrium value during the second half of the 1990's and beginning of the 2000's and above them during the housing boom of the 2000s. In particular, the maximum upward deviation of average national real housing prices was $28.2 \%$ in the second semester of 2007 . By contrast, according to the model, average national real housing prices were $11 \%$ below their fundamentals at the end of 2018.

All in all, the results obtained with pooled OLS are in line with those obtained with Within Group. However, we prefer the latter because Within Group allows us to control for all time-invariant characteristics of the province. For instance, housing prices in the islands and coastal provinces may be higher because of higher demand for second residences by foreigners and nationals from other provinces.

\section{Conclusions}

To assess the degree of deviation of prices from long-run equilibrium values of the housing market is crucial for detecting risks for financial stability and economic growth. This is especially important in the case of countries such as Spain, in which the collapse of the housing bubble ten years ago had very negative consequences on both the country's banking sector and the real economy. The ongoing recovery period of housing prices, started in 2014, renewed attention in the housing sector and highlighted the importance of detecting deviations of house prices from the level implied by their fundamentals.

In order to do so, traditionally, aggregate time series models have been employed. These models relate the evolution of some national house price index with the 
developments of fundamentals such a per capita income or interest rates to test whether the former is aligned with the latter. However, this is a useful but incomplete perspective, because housing is a very local phenomenon: there is not a single Spanish housing market, but many regional housing markets. This is evidenced in the period 2014-2018, in which house prices registered robust growth in some regions but not in others, which were still experiencing a correction from the previous boom.

We attempt to fill this gap by estimating the long-run relationship between real house prices and their fundamentals in the 50 Spanish provinces for the period 1985 to 2018. Using panel data techniques we find a cointegrating relationship between real house prices, per capita real income, the unemployment rate and population density. As provinces in Spain are substantially heterogeneous, we include fixed effects to account for time-invariant unobserved factors such as location, climate and culture.

Our main findings indicate that housing prices were significantly above the long-run equilibrium levels determined by fundamentals in most Spanish provinces in 2007 , the peak of the boom. However, there was substantial regional heterogeneity, as deviations ranged between 6\% and 58\%. By contrast, at the end of 2018 real housing prices were somewhat below the long-run equilibrium levels in most provinces. Nevertheless, a few provinces exhibited moderate levels of upward deviation, with a regional maximum of $13 \%$.

However, the external validity of our results may be limited by the fact that our sample only comprises data on new houses. This may be a cause of concern because of the low number of transactions of new houses in the ongoing period of recovery, around $10 \%$ of the total transactions. In this regard, it is also worth noting that the series of prices we use exhibit a smoother behaviour than official series published by the National Statistics Institute.

While we believe that modelling house prices at the province level is a step in the right direction, it may hide deviations from long-run equilibrium levels that take place at a local level, such as cities or districts. Therefore, further research may be needed at a more disaggregated level, because it might define the correct market. Nevertheless, this approach may be especially challenging, because it may be 
difficult to find classic measures of fundamentals (e.g. income) at that level, which would require the use of other explanatory variables or methodologies.

Finally, deviations of housing prices from their fundamentals should not be considered as a measure of housing affordability but rather an approximate indication of the housing market stance. In particular, the evolution of fundamentals driving the increase of long-term equilibrium house prices during the recovery period do not necessarily imply greater housing affordability, especially for the most vulnerable segments of population and areas where house demand has concentrated in recent years. 
real housing price

real per capita income

unemployment rate nominal interest rate per capita housing stock population density proportion 30 to 54 years housing credit to income real construction costs
Natural logarithm of real housing prices. Nominal housing prices have been deflated by the province CPI. Source: Sociedad de Tasación and National Statistics Institute.

Natural logarithm of per capita real gross disposable income. Nominal gross disposable income has been deflated by the province CPI. Source: Banco de España and National Statistics Institute.

Unemployed population over active population. Source: National Statistics Institute.

Mortgage interest rate of new operations (effective anual rate). Source: Banco de España.

Natural logarithm of per capita housing stock. Source: Ministry of Public Works and Infraestructure, National Statistics Institute, CSCAE.

Natural logarithm of total province population divided by the province area. Source: National Statistics Institute and National Geographic Institute.

Percentage of population between 30 and 54 years in the province. Source: National Statistics Institute.

Ratio between housing credit and gross disposable income, in percentage. Source: Banco de España.

Index of construction costs deflated by province CPI. Source: Ministry of Public Works and Infraestructure and National Statistics Institute. 
Table 2: CD tests and average cross-section correlation coefficients.

The table displays CD tests (Pesaran 2004) and average cross-section correlation coefficients computed with the residuals of ADF (4) regressions for each variable and each cross-section separately.

\begin{tabular}{lccc}
\hline Variable & CD-test statistic & $\mathrm{p}$-value & average correlation coefficient \\
\hline real housing price & 100.43 & 0.000 & 0.367 \\
real per capita income & 241.85 & 0.000 & 0.885 \\
unemployment rate & 79.99 & 0.000 & 0.290 \\
per capita housing stock & 86.49 & 0.000 & 0.316 \\
population density & 130.27 & 0.000 & 0.477 \\
proportion 30 to 54 years & 185.23 & 0.000 & 0.678 \\
housing credit to income & 248.23 & 0.000 & 0.908 \\
real construction costs & 246.84 & 0.000 & 0.896
\end{tabular}

Table 3: Panel unit root tests

The reported values are CIPS(p) statistics, which are cross-section averages of Cross-sectionally Augmented Dickey-Fuller (CADF(p)) test statistics (Pesaran, 2007).

The null hypothesis is that all series contain a unit root, while the alternative hypothesis is that some series are stationary. P-values are in parenthesis. In the case of the nominal interest rate, the reported values come from Augmented Dickey-Fuller tests.

\begin{tabular}{lcccc}
\hline Variable & CADF(1) & CADF(2) & CADF(3) & CADF(4) \\
\hline real housing price & -3.388 & -3.492 & -3.307 & -3.377 \\
per capita real income & $(0.000)$ & $(0.000)$ & $(0.000)$ & $(0.000)$ \\
& -1.512 & -2.124 & -1.773 & -2.071 \\
unemployment rate & $(1.000)$ & $(0.969)$ & $(1.000)$ & $(0.989)$ \\
& -2.539 & -2.170 & -1.978 & -1.710 \\
per capita housing stock & $(0.000)$ & $(0.001)$ & $(0.064)$ & $(0.705)$ \\
& -2.849 & -3.173 & -3.118 & -3.323 \\
population density & $(0.000)$ & $(0.000)$ & $(0.000)$ & $(0.000)$ \\
& -1.641 & -1.723 & -1.730 & -1.819 \\
nominal interest rate & $(1.000)$ & $(1.000)$ & $(1.000)$ & $(1.000)$ \\
& -2.184 & -1.453 & -1.457 & -1.796 \\
proportion 30 to 54 years & $(0.4991)$ & $(0.8445)$ & $(0.8435)$ & $(0.7065)$ \\
& -2.157 & -2.226 & -2.134 & -2.035 \\
housing credit to income & $(0.944)$ & $(0.847)$ & $(0.962)$ & $(0.995)$ \\
& -1.511 & -0.861 & -1.224 & -0.702 \\
real construction costs & $(1.000)$ & $(1.000)$ & $(1.000)$ & $(1.000)$ \\
& -1.975 & -2.008 & -1.858 & -1.948 \\
& $(0.067)$ & $(0.040)$ & $(0.274)$ & $(0.099)$
\end{tabular}


Table 4: cointegration vector

The table displays the cointegration vector between housing prices, per capital real income, unemployment rate and population density. It is estimated by Within-Group to account for province fixed effects. It also includes two lags and two leads of $\Delta x$, and contemporaneous changes $\Delta \mathrm{x}$. Discroll-Kraay standard errors in parenthesis.

\begin{tabular}{lc}
\hline & \\
VARIABLES & real housing price \\
\hline & \\
per capita real income & $\left(0.629^{* * *}\right.$ \\
& $-0.009^{* *}$ \\
unemployment rate & $(0.003)$ \\
& $1.032^{* * *}$ \\
population density & $(0.162)$ \\
& YES \\
Province fixed effects & 3,100 \\
Observations & 0.713 \\
R-squared & $131.57^{* * *}$ \\
CD-test &
\end{tabular}

Table 5: CIPS tests of the residuals

The reported values are CIPS(p) statistics, which are cross-section averages of Cross-sectionally Augmented Dickey-Fuller (CADF(p)) test statistics (Pesaran, 2007). The critical values $(\mathrm{N}=50, \mathrm{~T}=61)$ for the model with an intercept are $-2.05,-2.12$ and -2.23 for $10 \%, 5 \%$ and $1 \%$, respectively. P-values in parenthesis.

\begin{tabular}{cccc}
\hline CADF (1) & CADF (2) & CADF (3) & CADF (4) \\
-2.820 & -2.636 & -2.682 & -2.338 \\
$(0.000)$ & $(0.000)$ & $(0.000)$ & $(0.000)$ \\
\hline
\end{tabular}


This table presents the estimation of the Error Correction Model with two estimators, Dynamic Fixed Effects and Pooled Mean Group. With Dynamic Fixed Effects all parameters, except intercepts, are constrained to be equal across panels. With Pooled Mean Group, long-run effects are constrained to be equal across all panels, while short-run coefficients, including the speed of adjustment, are allowed to differ across panels. Discroll-Kraay standard errors in parenthesis.

\begin{tabular}{lcc}
\hline & $(1)$ & $(2)$ \\
\hline ESTIMATOR & DYNAMIC FIXED EFFECTS & POOLED MEAN GROUP \\
\hline VARIABLES & D.housing price & D.housing price \\
Error correction term (t-1) & $-0.068^{* * *}$ & \\
& $(0.014)$ & $-0.085^{* * *}$ \\
D.housing price (t-1) & $0.527^{* * *}$ & $(0.006)$ \\
& $(0.058)$ & $0.503^{* * *}$ \\
D.income (t) & $0.735^{* * *}$ & $(0.020)$ \\
& $(0.123)$ & $0.686^{* * *}$ \\
D.income (t-1) & -0.091 & $(0.041)$ \\
& $(0.146)$ & -0.070 \\
D.unemployment rate (t) & $-0.001^{*}$ & $(0.049)$ \\
& $(0.001)$ & $-0.002 * * *$ \\
D.unemployment rate $(\mathrm{t}-1)$ & 0.000 & $(0.000)$ \\
& $(0.001)$ & 0.000 \\
D.population density $(\mathrm{t})$ & 1.213 & $(0.000)$ \\
& $(1.506)$ & $1.678^{* * *}$ \\
D.population density $(\mathrm{t}-1)$ & 0.522 & $(0.464)$ \\
& $(1.924)$ & $0.843^{* *}$ \\
\hline Observations & 3,250 & $(0.427)$ \\
R-squared & 0.5313 & 3,250 \\
CD-test & $101.30^{* * *}$ & - \\
\hline
\end{tabular}


Table 7: speed of adjustment across Spanish provinces.

This table presents the estimation of the speed of adjustment for the 50 Spanish provinces via Pooled Mean Group.

\begin{tabular}{|c|c|}
\hline Province & Speed of adjustment \\
\hline PALENCIA & $-0.212 * * *$ \\
\hline ÁVILA & $-0.165 * * *$ \\
\hline LLEIDA & $-0.156 * * *$ \\
\hline VALLADOLID & $-0.145 * * *$ \\
\hline CÓRDOBA & $-0.138 * * *$ \\
\hline SORIA & $-0.133 * * *$ \\
\hline BIZKAIA & $-0.127 * * *$ \\
\hline ZARAGOZA & $-0.124 * * *$ \\
\hline SEGOVIA & $-0.123 * * *$ \\
\hline HUELVA & $-0.121 * * *$ \\
\hline ZAMORA & $-0.115 * * *$ \\
\hline JAÉN & $-0.108^{* * *}$ \\
\hline BARCELONA & $-0.106^{* * *}$ \\
\hline OURENSE & $-0.106 * *$ \\
\hline LEÓN & $-0.101 * * *$ \\
\hline ALMERÍA & $-0.099 * * *$ \\
\hline PALMAS, LAS & $-0.099 * * *$ \\
\hline CORUÑA, A & $-0.098 * *$ \\
\hline PONTEVEDRA & $-0.097^{* *}$ \\
\hline BURGOS & $-0.093 * * *$ \\
\hline SEVILLA & $-0.086 * * *$ \\
\hline CÁCERES & $-0.084^{* *}$ \\
\hline GUADALAJARA & $-0.082^{* *}$ \\
\hline ALBACETE & $-0.080 * *$ \\
\hline ASTURIAS & $-0.079 * * *$ \\
\hline SALAMANCA & $-0.075^{* *}$ \\
\hline BALEARS, ILLES & $-0.072 * *$ \\
\hline GRANADA & $-0.071^{* *}$ \\
\hline CÁDIZ & $-0.070 * *$ \\
\hline CANTABRIA & $-0.067^{* *}$ \\
\hline LUGO & $-0.066 * *$ \\
\hline VALENCIA & $-0.065^{* *}$ \\
\hline ALICANTE & $-0.061 * *$ \\
\hline CASTELLÓN & $-0.061 * *$ \\
\hline CUENCA & $-0.059 * *$ \\
\hline TERUEL & $-0.059 * *$ \\
\hline BADAJOZ & $-0.055^{* *}$ \\
\hline HUESCA & $-0.055^{*}$ \\
\hline NAVARRA & $-0.052 *$ \\
\hline MÁLAGA & $-0.051 * *$ \\
\hline CIUDAD REAL & $-0.050 * *$ \\
\hline MADRID & $-0.043^{* *}$ \\
\hline ÁLAVA & $-0.041^{* *}$ \\
\hline GIRONA & $-0.040^{*}$ \\
\hline RIOJA, LA & $-0.031 * *$ \\
\hline SANTA CRUZ DE TENERIFE & -0.024 \\
\hline TOLEDO & -0.038 \\
\hline TARRAGONA & -0.041 \\
\hline MURCIA & -0.042 \\
\hline GIPUZKOA & -0.063 \\
\hline
\end{tabular}


The table displays the cointegration vector between housing prices, per capital real income, unemployment rate, nominal interest rate, housing stock and population density. It is estimated by OLS. It also includes two lags and two leads of $\Delta \mathrm{x}$, and contemporaneous changes $\Delta \mathrm{x}$. Discroll-Kraay standard errors in parenthesis.

\begin{tabular}{lc}
\hline VARIABLES & housing price \\
\hline & \\
per capita real income & $0.409^{* * *}$ \\
& $(0.037)$ \\
unemployment rate & $-0.011^{* * *}$ \\
& $(0.002)$ \\
nominal interest rate & $-0.015^{* * *}$ \\
& $(0.004)$ \\
per capita housing stock & $-0.268^{* * *}$ \\
& $(0.045)$ \\
population density & $0.079^{* * *}$ \\
& $(0.008)$ \\
\hline Province fixed effects & $\mathrm{NO}$ \\
Observations & 3,100 \\
R-squared & 0.639 \\
CD-test & $136.22^{* * *}$
\end{tabular}

Table 9: CIPS tests of the residuals (alternative cointegration relationship)

The reported values are CIPS(p) statistics, which are cross-section averages of Cross-sectionally Augmented Dickey-Fuller (CADF(p)) test statistics (Pesaran, 2007). The critical values $(\mathrm{N}=50, \mathrm{~T}=61)$ for the model with an intercept are $-2.05,-2.12$ and -2.23 for $10 \%, 5 \%$ and $1 \%$, respectively. P-values in parenthesis.

\begin{tabular}{|cccc|}
\hline CADF (1) & CADF (2) & CADF (3) & CADF (4) \\
-2.532 & -2.406 & -2.320 & -2.083 \\
$(0.000)$ & $(0.000)$ & $(0.000)$ & $(0.010)$ \\
\hline
\end{tabular}


Figure 1: evolution of nominal housing prices between 1985 and 2018

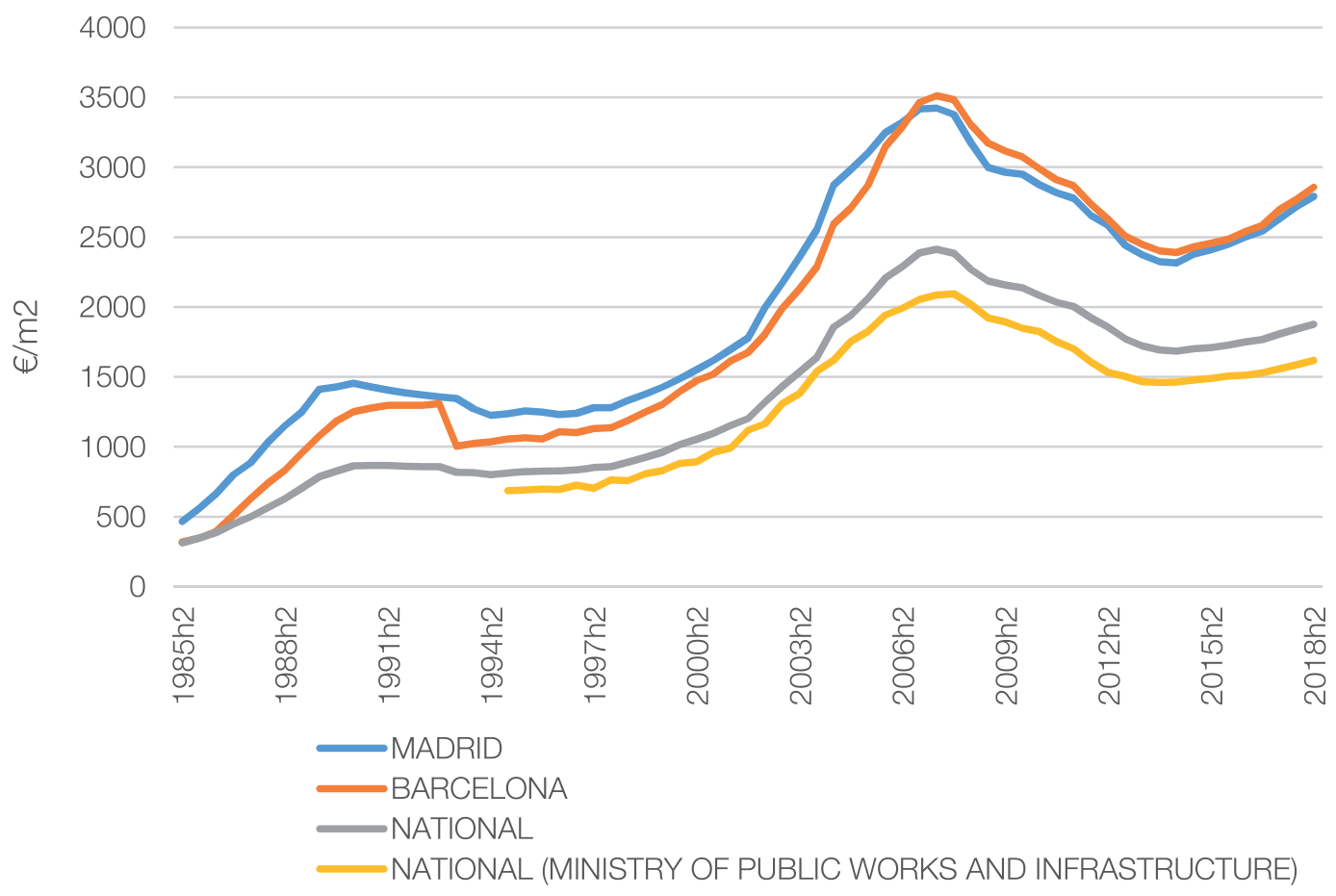


Figure 2: real housing price growth in the run-up to the crisis by provinces (1995h1-2007h1)

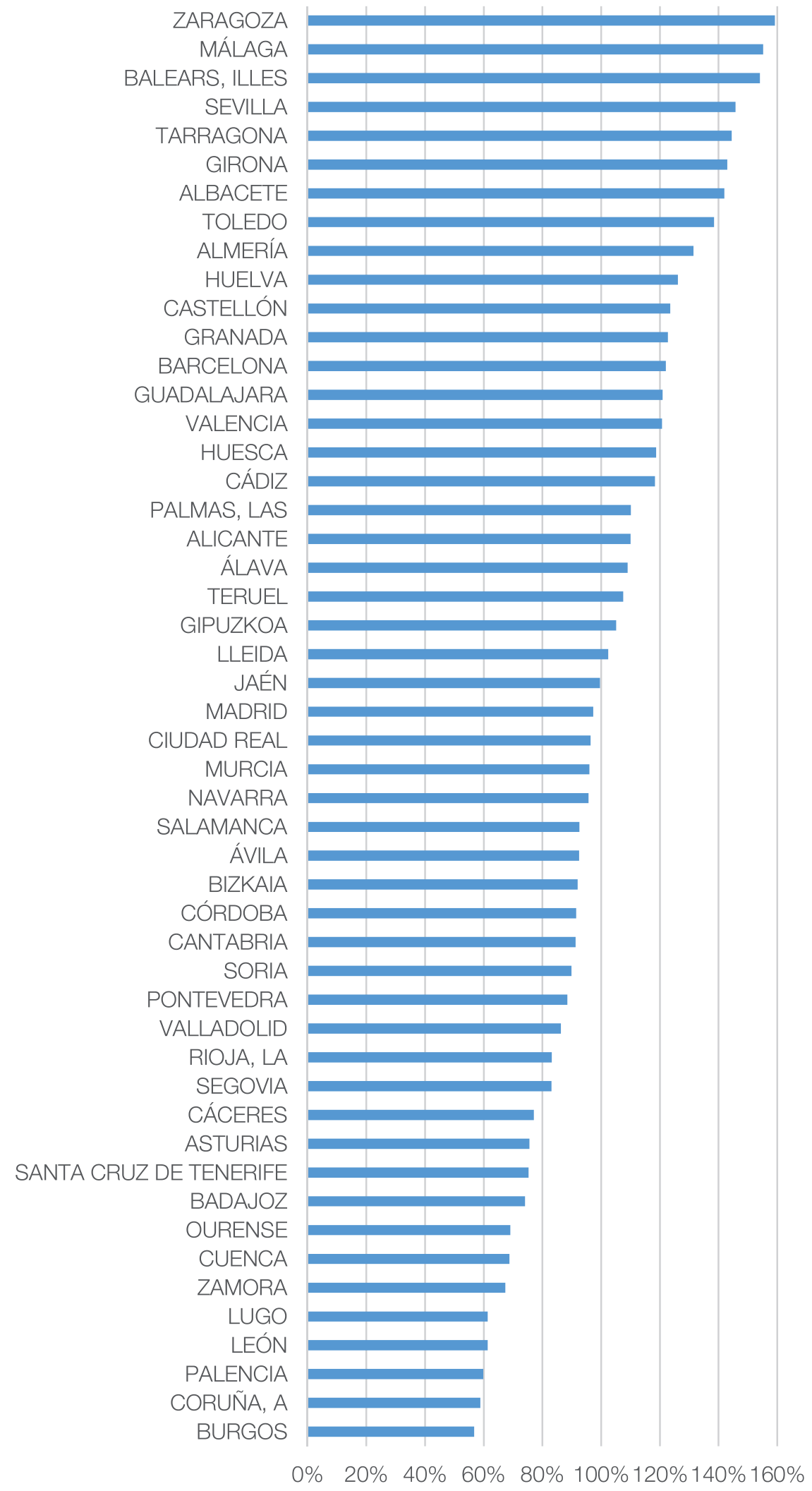


Figure 3: real housing price growth during the recovery by provinces

(2014h2-2018h2)

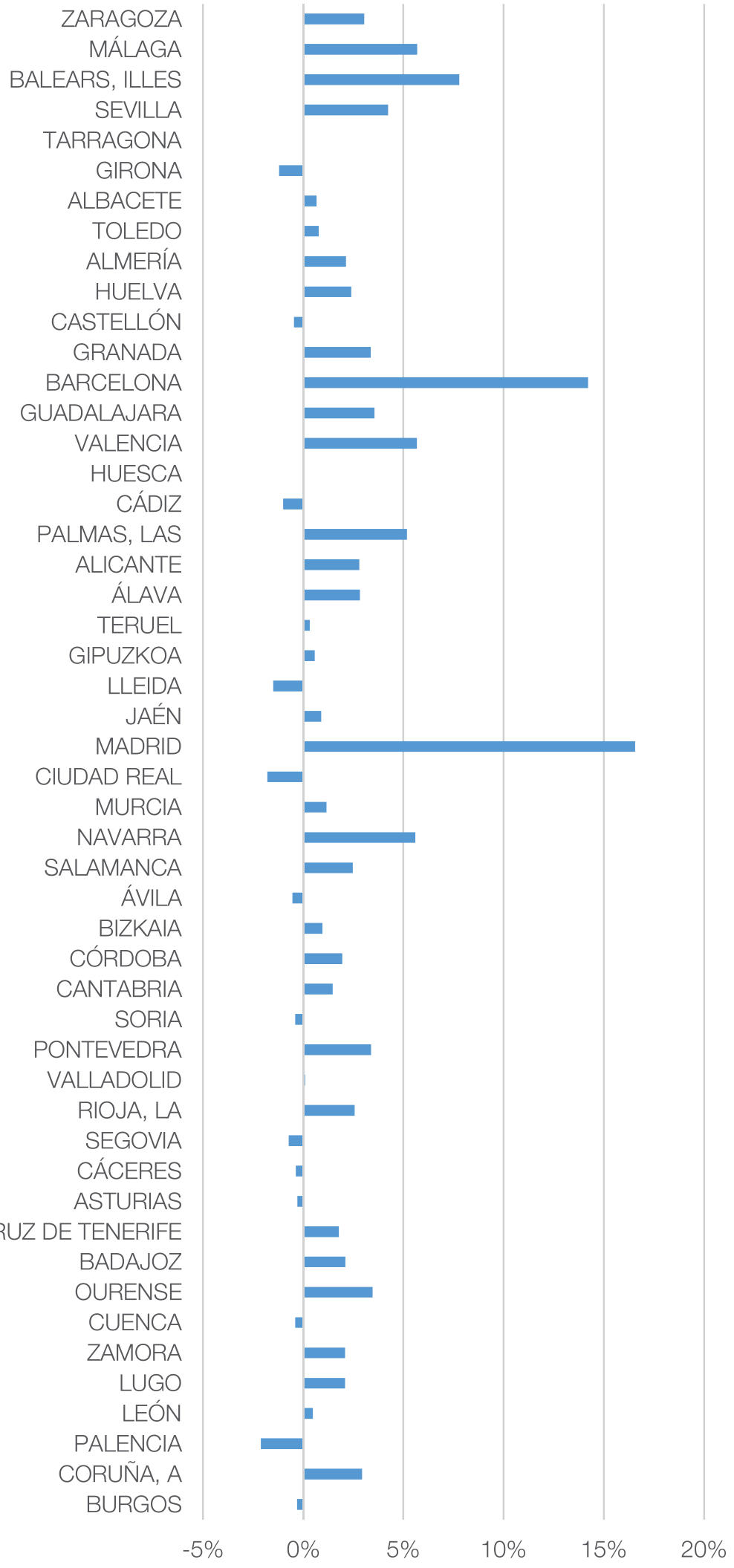


Figure 4: housing price (€/m2)-to-annual income per capita ratios for the 50 Spanish provinces in 2007 and 2018

$25 \%$

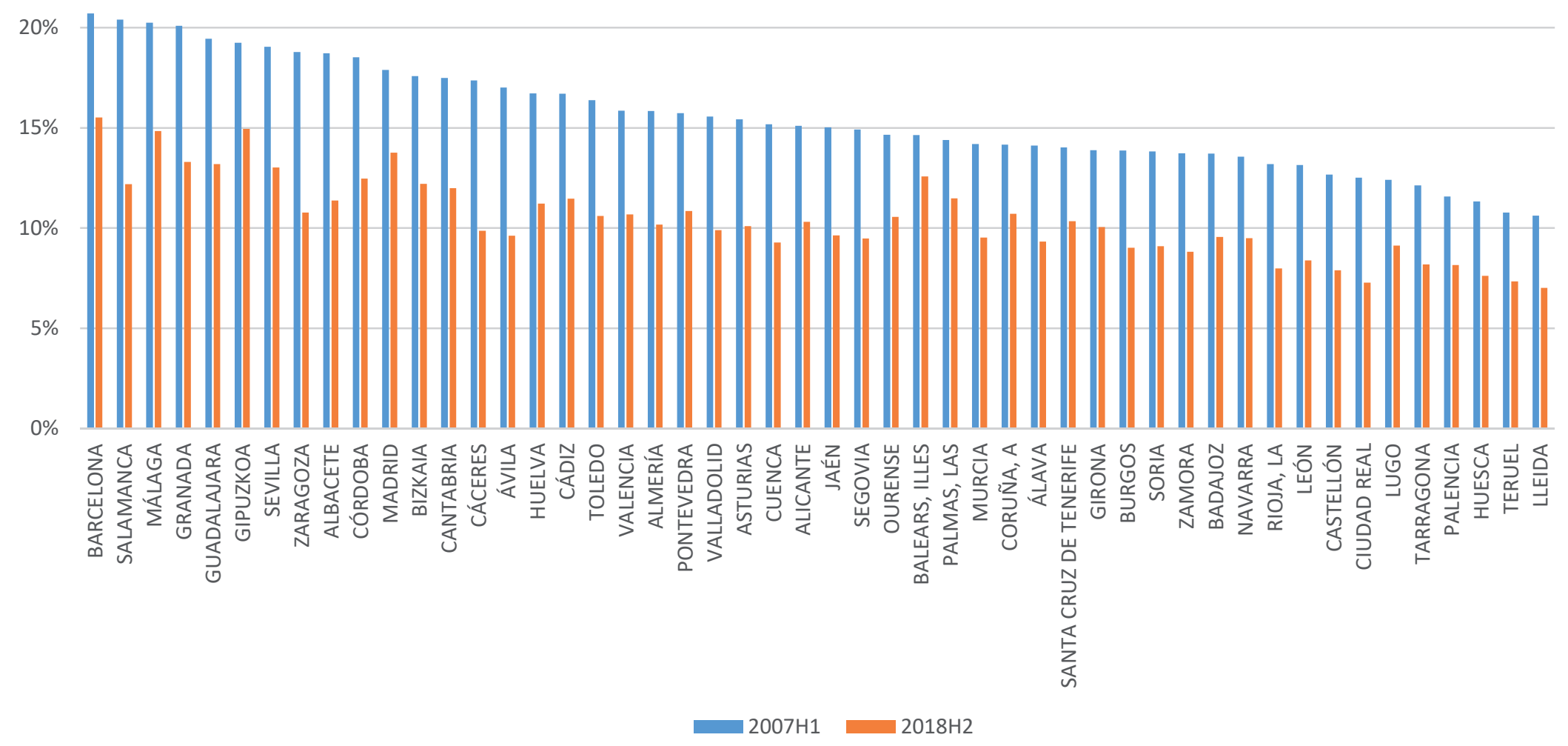


Figure 5: distribution of real house price deviations from long-run equilibrium by provinces

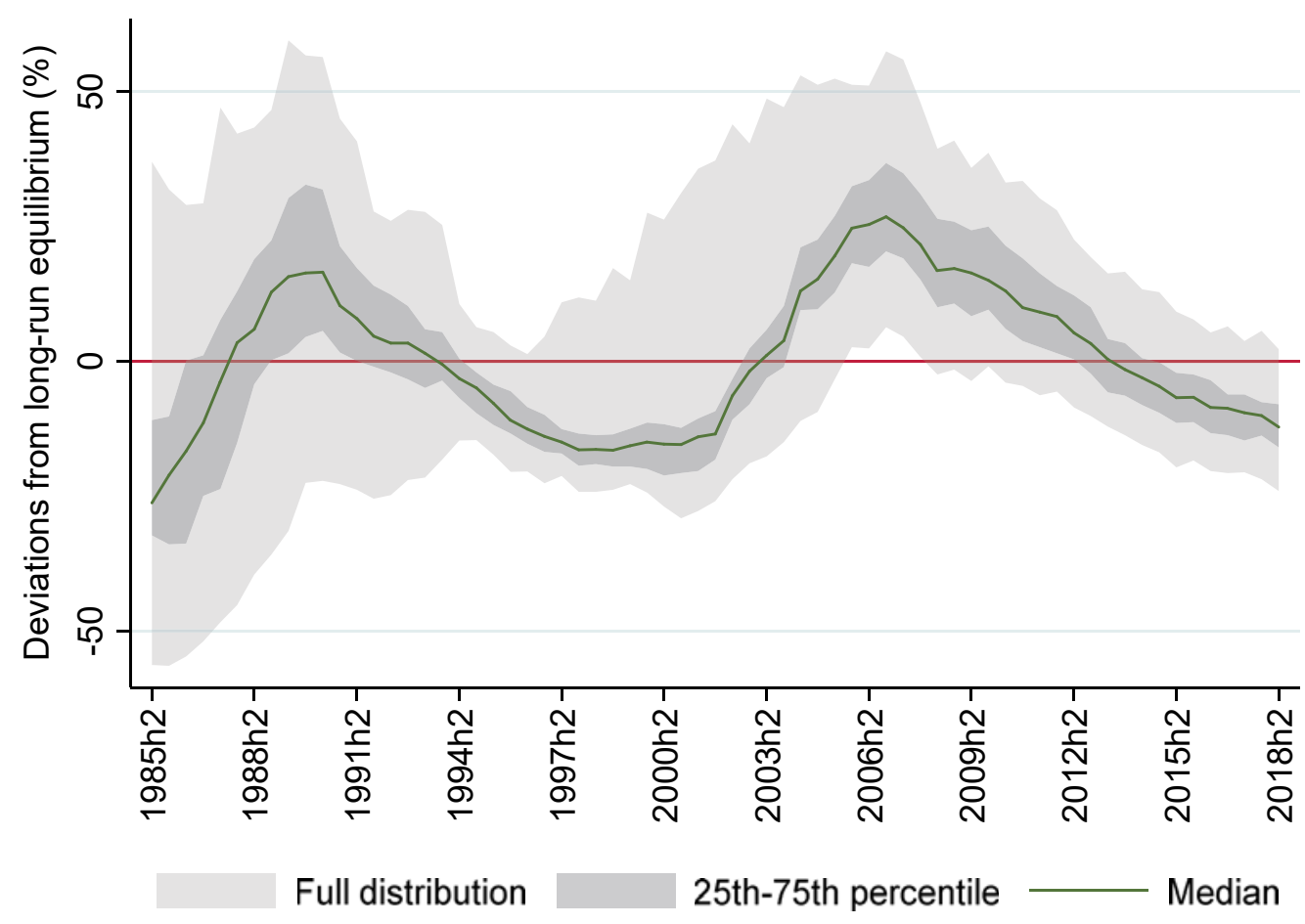

Figure 6: observed real housing prices and long-run equilibrium real values at the national level

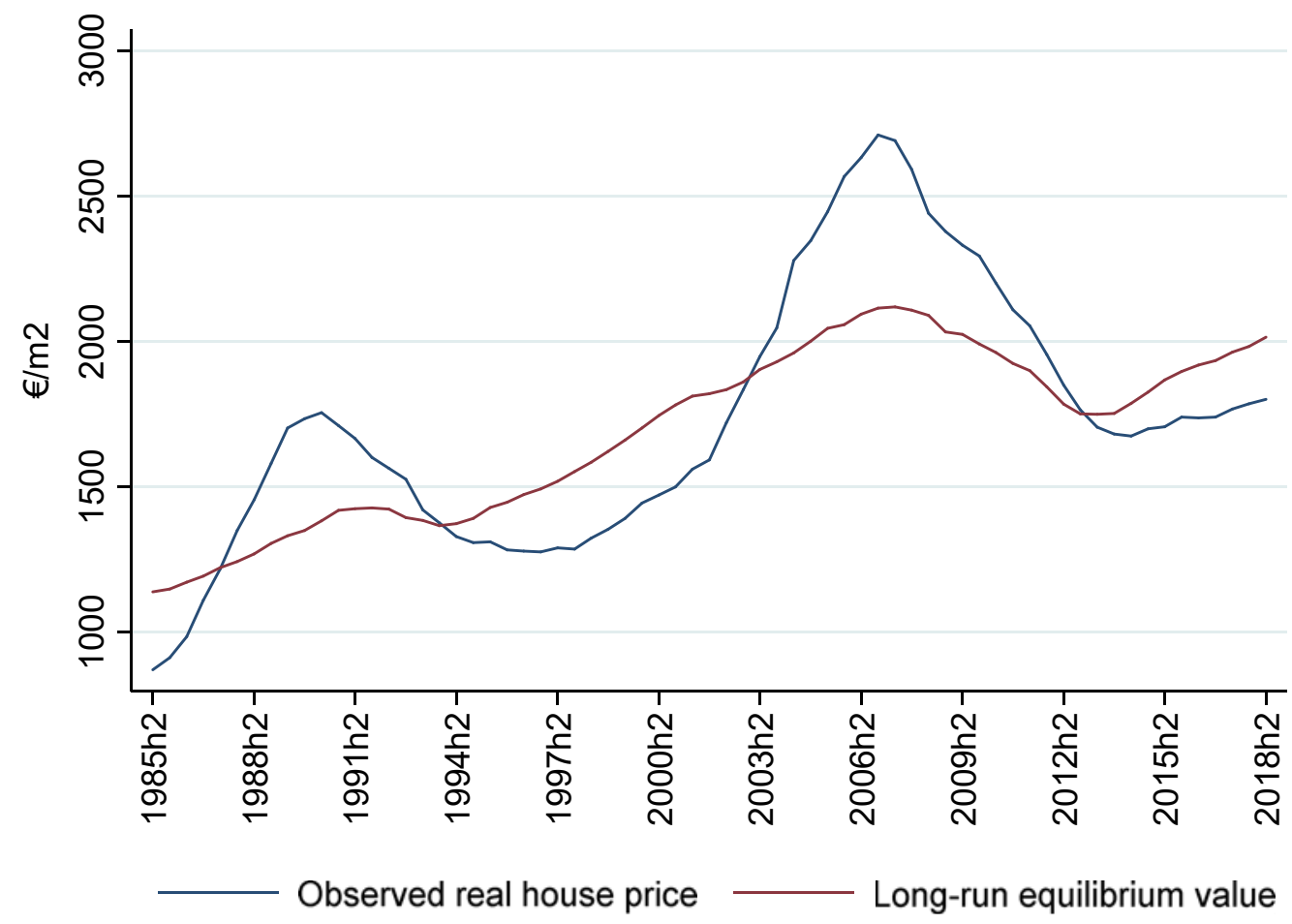


Figure 7: observed real housing prices and long-run equilibrium real values at the national level (Hodrick-Prescott filter)

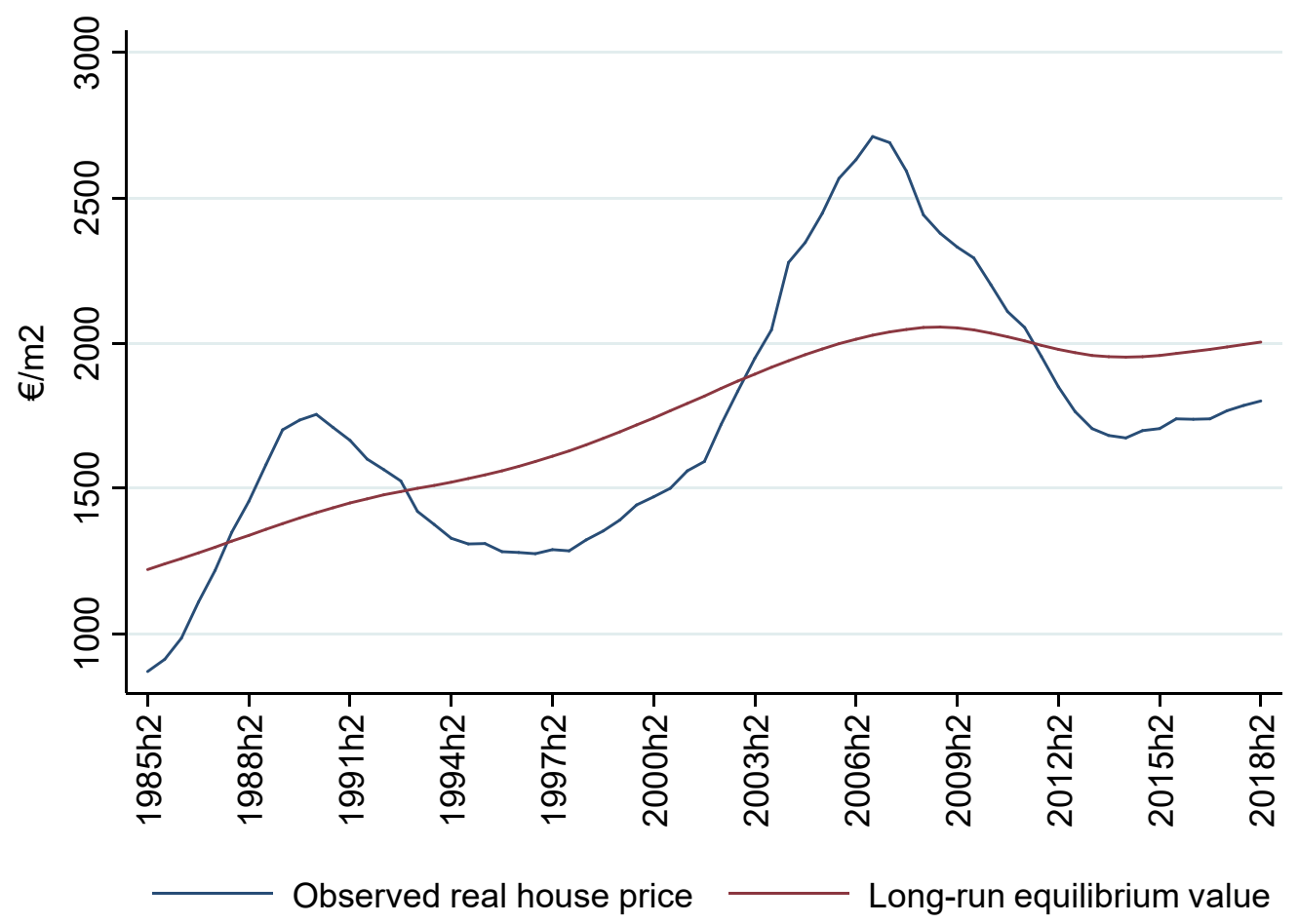

Figure 8: observed and predicted average growth of real housing prices, estimated by Dynamic Fixed Effects

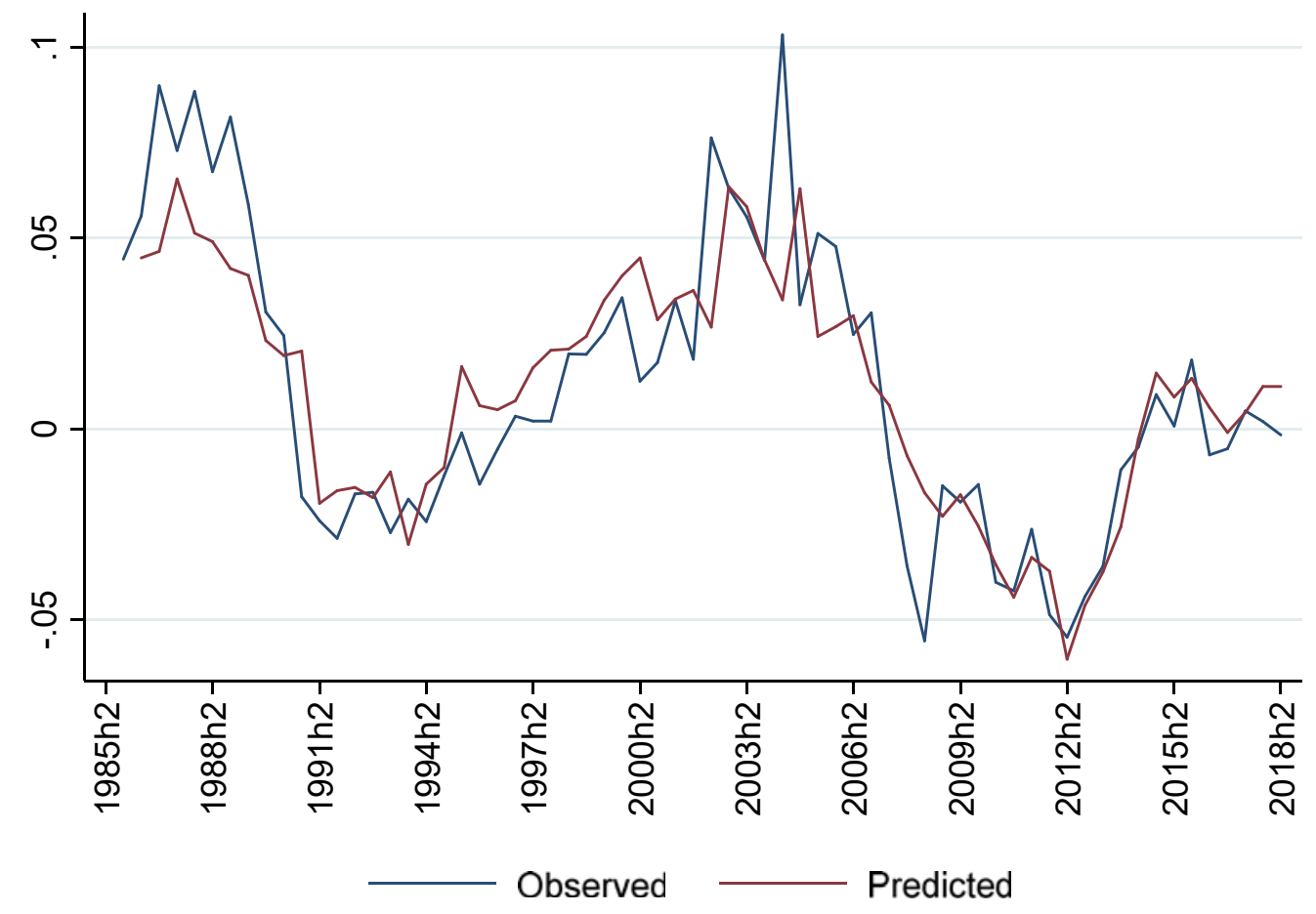


Figure 9: observed and predicted average growth of real housing prices, estimated by Mean Group

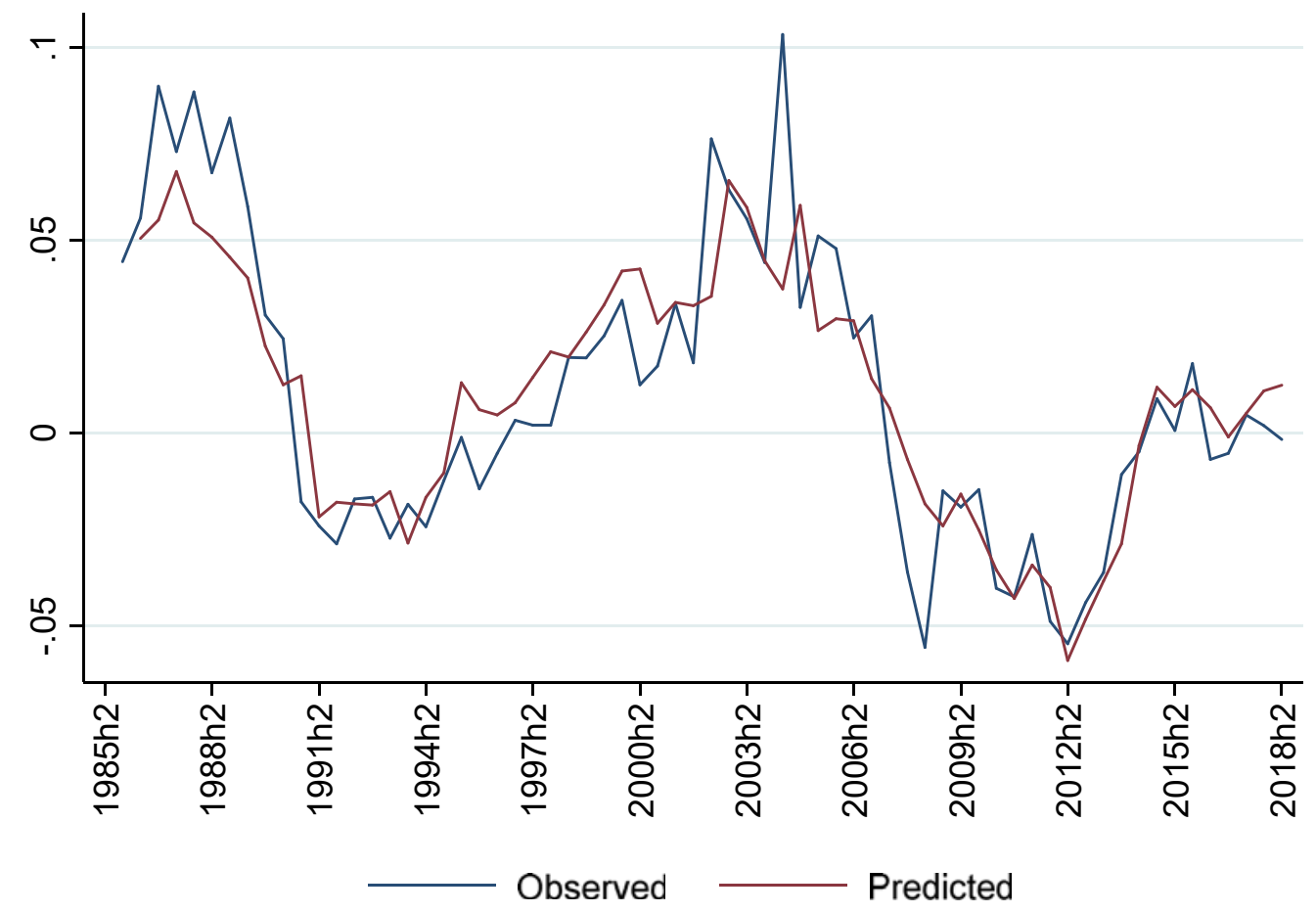

Figure 10: distribution of real house price deviations from long-run equilibrium by provinces (alternative cointegration relationship)

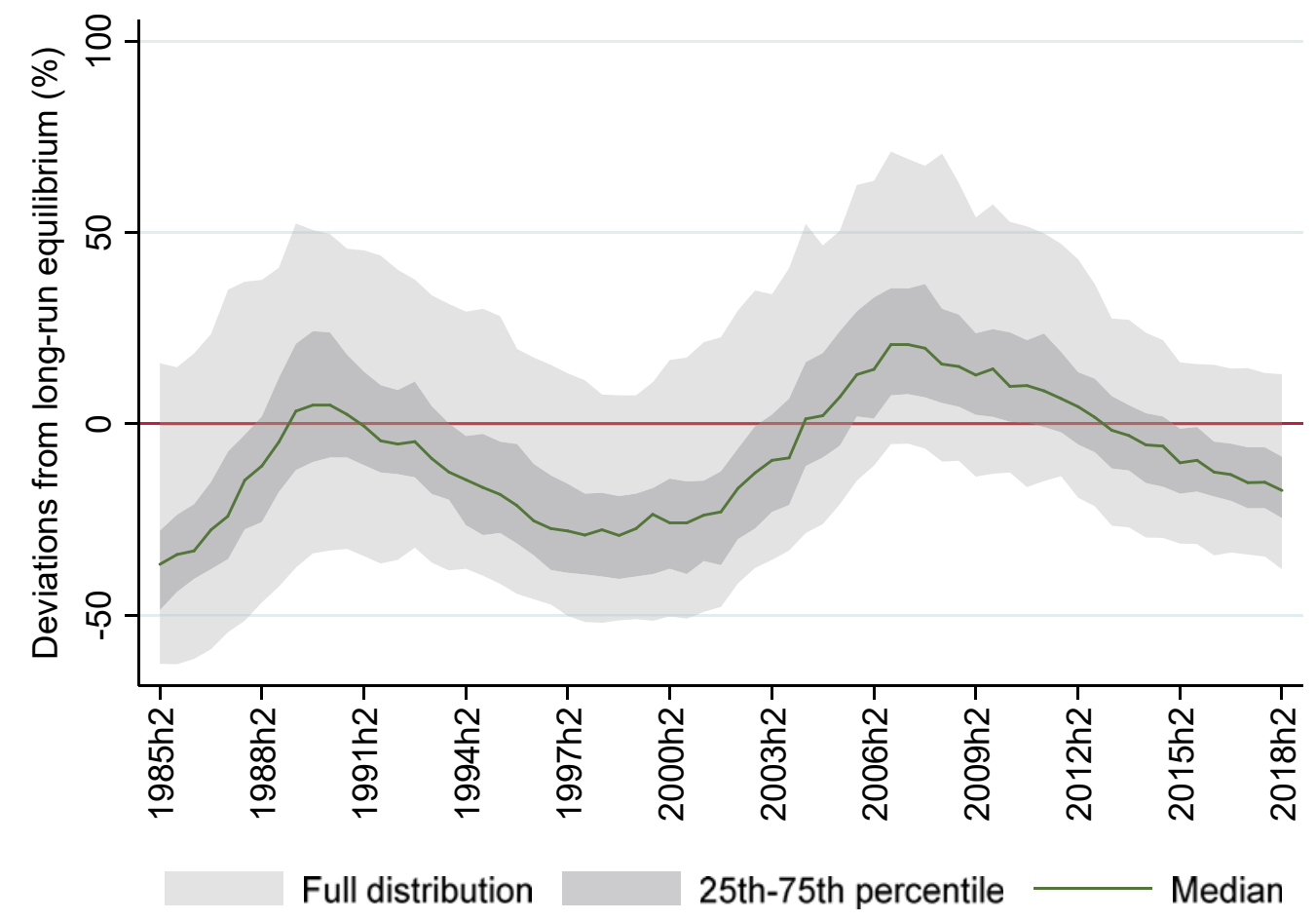


Figure 11: observed real housing prices and long-run equilibrium real values at the national level (alternative cointegration relationship)

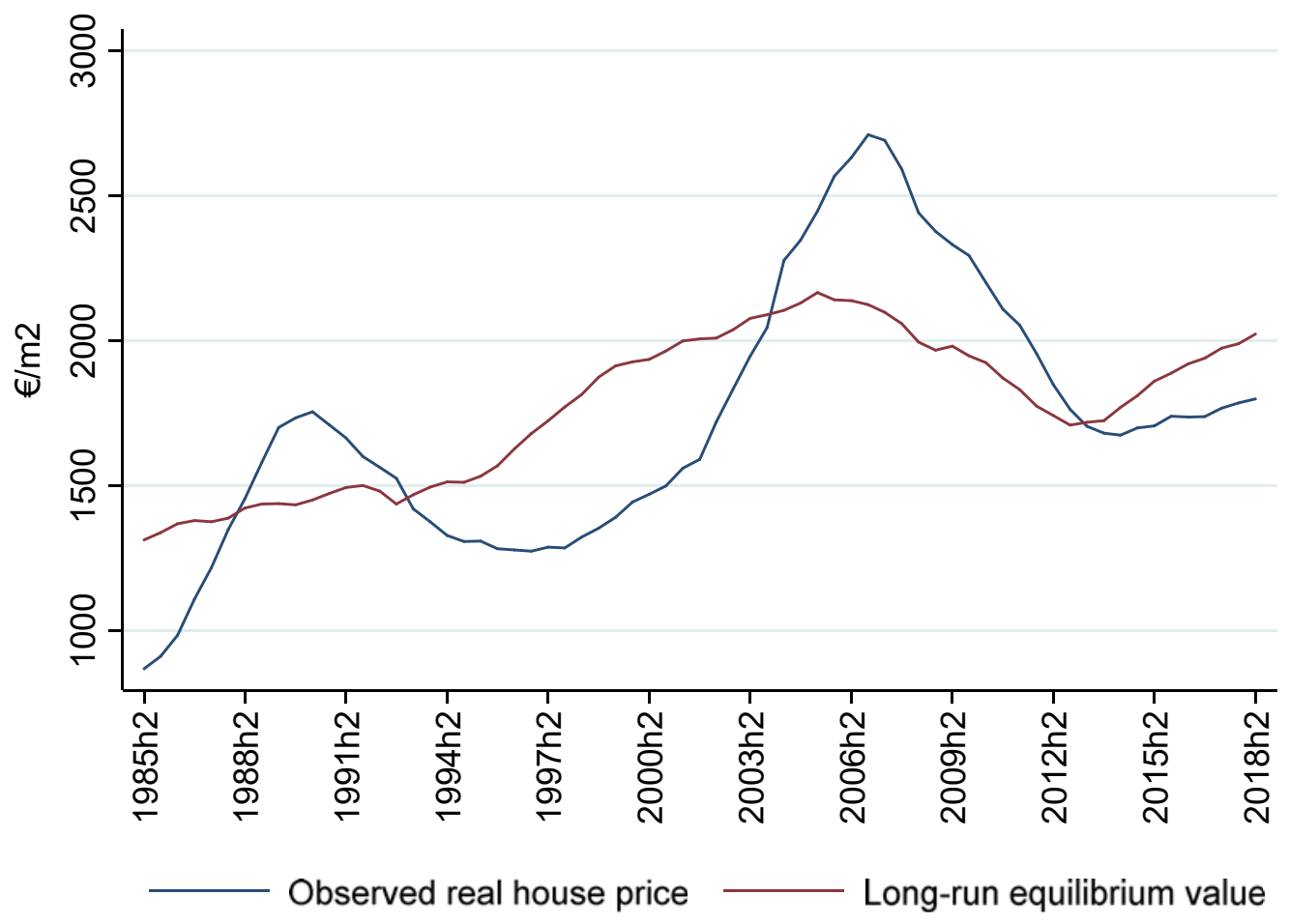




\section{REFERENCES}

Álvarez-Lois, P. and G. Nuño-Barrau (2007): "The Role of Fundamentals in the Price of Housing: Theory and Evidence", Working paper No 0701, BBVA Economic Research Department.

Banco de España (2019): "Informe de Estabilidad Financiera Primavera 2019".

Anghel, B., Basso, H., Bover, O., Casado, J.M., Hospido, L., Izquierdo, M., Kataryniuk, I., Lacuesta, A., Montero, J.M and E. Vozmediano (2018): "La desigualdad de la renta, el consumo y la riqueza en España" Documentos ocasionales n¹806, Banco de España.

Bundesbank (2013): "An approach to estimating fundamental house prices based on regional data", Deutsche Bundesbank Monthly Report, October, pp. 18-20.

Capozza, D. R., Hendershott, P.H., Mack, C. and C.J. Mayer (2002): "Determinants of real house price dynamics", NBER Working Paper 9262.

Eurostat (2013): "Handbook on Residential Property Prices Indices (RPPIs)", Methodologies and Working papers, available at https://ec.europa.eu/eurostat/en/web/products-manuals-and-guidelines/-/KS-RA$12-022$

Gallin, J. (2006): "The long run relationship between house prices and income: evidence from local housing markets", Real Estate Economics 34, pp. 417-438.

Gan, L., Wang, P. and Q. Zhang (2018): "Market thickness and the impact of unemployment on housing market outcomes", Journal of Monetary Economics, Volume 98, Pages 27-49.

García-Montalvo, J. (2001): “Un análisis empírico del crecimiento del precio de la vivienda en las comunidades autónomas españolas," RVEH N².

Gimeno, R. and C. Martínez-Carrascal (2010): "The relationship between house prices and house purchase loans: The Spanish case", Journal of Banking \& Finance 34, pp. 1849-1855.

Lessard, D. and F. Modigliani (1975): "Inflation and the housing market: problems and potential solution", Sloan Management Review, fall. 
López-Rodríguez, D. and M. Llanos (2019): "Evolución reciente del mercado del alquiler de vivienda en España", Boletín Económico 3/2019, Banco de España.

Holly, S., Pesaran, M. H. and T. Yamagata (2010): "A spatio-temporal model of house prices in the USA", Journal of Econometrics, pp. 160-173.

Im, K., Pesaran, M. H. and Y. Shin (2003): "Testing for unit roots in heterogenenous panels", Journal of Econometrics 115, p. 53-74.

IMF (2008): "World Economic Outlook April 2008. Housing and the Business Cycle".

Kao, C. and M. Chiang (2000): "On the Estimation and Inference of a Cointegrated Regression in Panel Data", Nonstationary Panels, Panel Cointegration and Dynamic Panels, Advances in Econometrics, 15, JAl Press. pp. 179-222.

Malpezzi, S. (1999): "A simple error correction model of house prices", Journal of Housing Economics 8, p. 27-62.

Martínez-Pagés, J. and L. A. Maza (2003): "Análisis del precio de la vivienda en España", Banco de España Working Paper 0307.

Nickell, S. (2002): "Monetary policy issues: past, present and future", Bank of England, Quarterly Bulletin, autumn.

Pesaran, H. (1997): "The Role of Economic Theory in Modelling the Long Run", The Economic Journal, Vol. 107, No. 440 (Jan., 1997), pp. 178-191

Pesaran, M. H. (2007): "A simple panel unit root test in the presence of crosssection dependence", Journal of Applied Econometrics 22, p. 265-312.

Pesaran, H., Y. Shin and R. P. Smith (1999): "Pooled Mean Group Estimation of Dynamic Heterogeneous Panels", Journal of the American Statistical Association, Vol. 94, No. 446 (Jun., 1999), pp. 621-634.

Pesaran, M. H. (2004): "General diagnostic tests for cross section dependence in panels", CESifo Working Papers No. 1233.

Stock, J. H. and M. W. Watson (1993): "A Simple Estimator of Cointegrating Vectors in Higher Order Integrated Systems", Econometrica 61, pp. 783-820.

Wooldridge, J. (2003): Introductory Econometrics: a Modern Approach. Thomson South-western. 


\section{DATA APPENDIX}

Our database contains half-yearly data for Spain from 1985h2 to $2018 \mathrm{~h} 2$.

Housing price data is from Sociedad de Tasación (SdT), which comprises half-yearly data from 1985 to 2018 for 358 Spanish cities, including all provincial capitals, municipalities with more than 50,000 inhabitants and other smaller towns with relevant real estate activity. ${ }^{14}$ This dataset only includes prices of non-protected new houses that are considered representative ${ }^{15}$. Prices are negotiated offer prices obtained through a fieldwork in which SdT agent's visit or contact promotions pretending to be a buyer. All collected data is filtered for outliers and aggregated through stratification to avoid compositional effects. We aggregate municipal prices at the province level by creating a weighted average, using as weights the annual population of each municipality, obtained from National Statistics Institute (INE).

Gross disposable income is only available at the national level. To construct its regional counterpart, we compute each province average weight in national GDP (from 2000 to 2016) and assume that household's regional gross disposable is distributed according to these weights. Household's national gross disposable income and GDP data are obtained from Bank of Spain and INE, respectively.

Housing stock per capita is constructed using the annual stock of total dwellings of the INE censuses of 2001 and 2011. Non-census years are completed adding the flow of finished houses, both free and protected, from the Ministry of Public Works and Infrastructure and detracting an implicit depreciation rate so that they match the censuses stocks. Since data on finished houses starts in 1991, we extend it until 1985 using the annual growth rate of housing visas from the Superior Council of Colleges of Architects of Spain.

Construction costs include residential and non-residential buildings.

Monthly variables and quarterly variables have been converted into semi-annual frequency by averaging them. Annual variables have been converted into semiannual through interpolation.

\footnotetext{
${ }^{14}$ Until 1993 only data from provincial capitals is provided.

${ }^{15}$ Details on the characteristics that define the sample can be found in the methodology of "New Housing Market Study" from SdT, available at https://www.st-tasacion.es/es/metodologia-estudiomercado-vivienda-nueva.html.
} 
A.1 Average population density

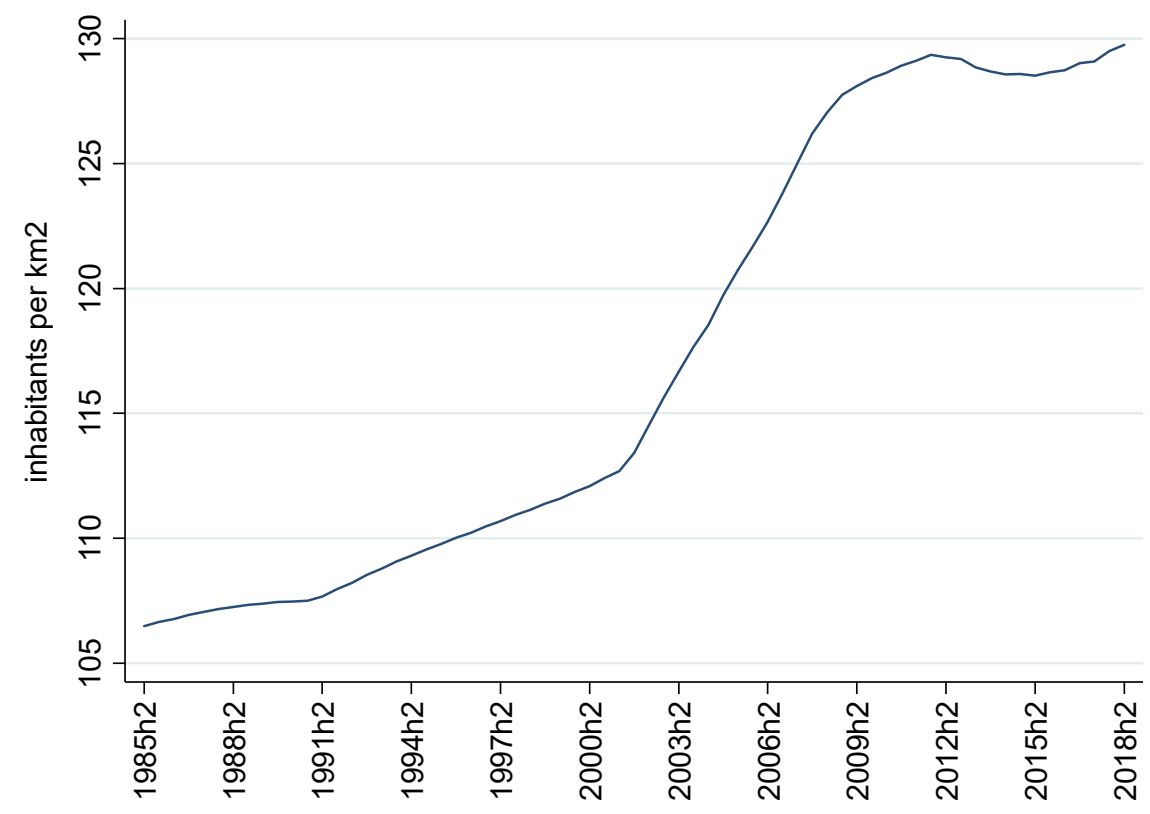

A.2 Average unemployment rate

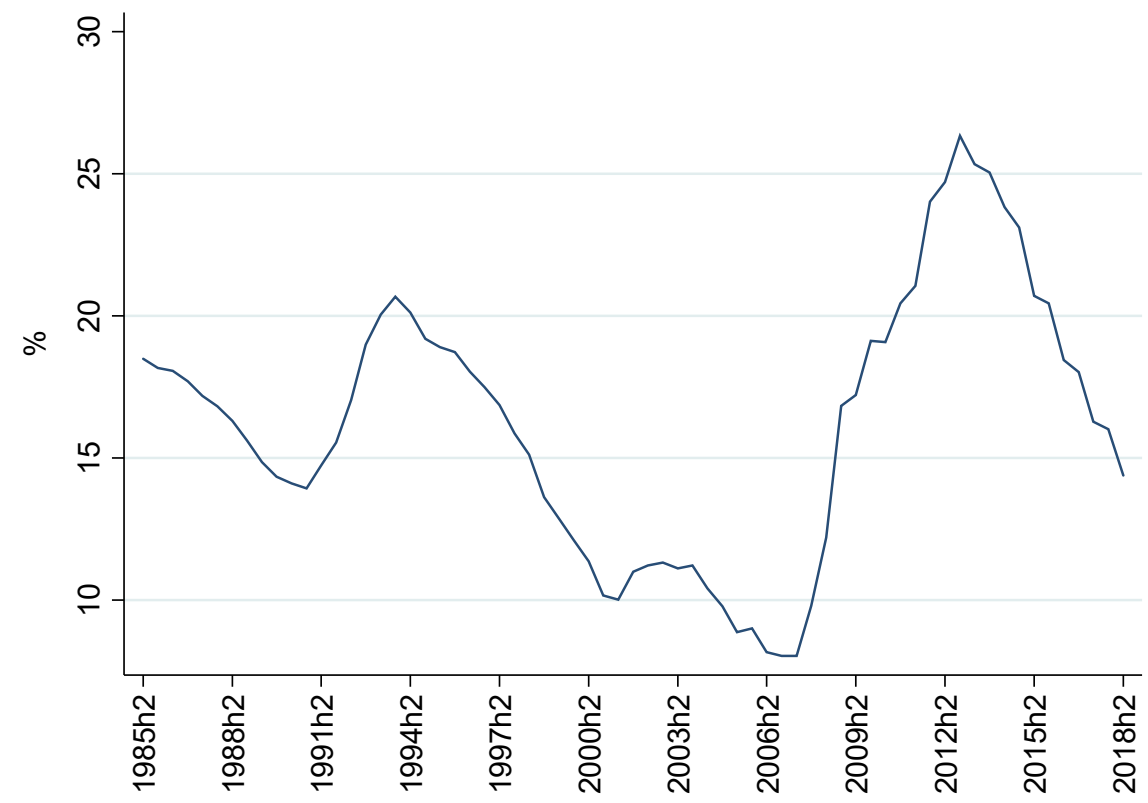


A.3 Average real annual per capita income

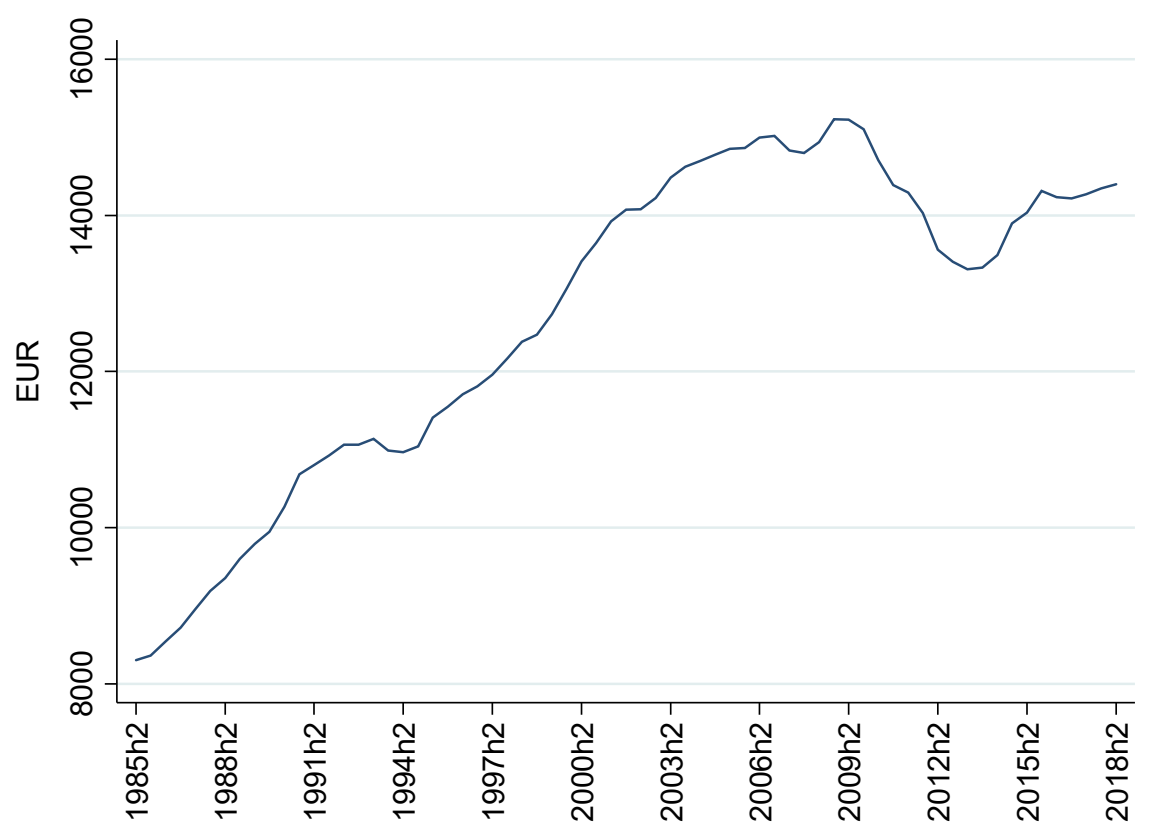

A.4 Nominal mortgage interest rate

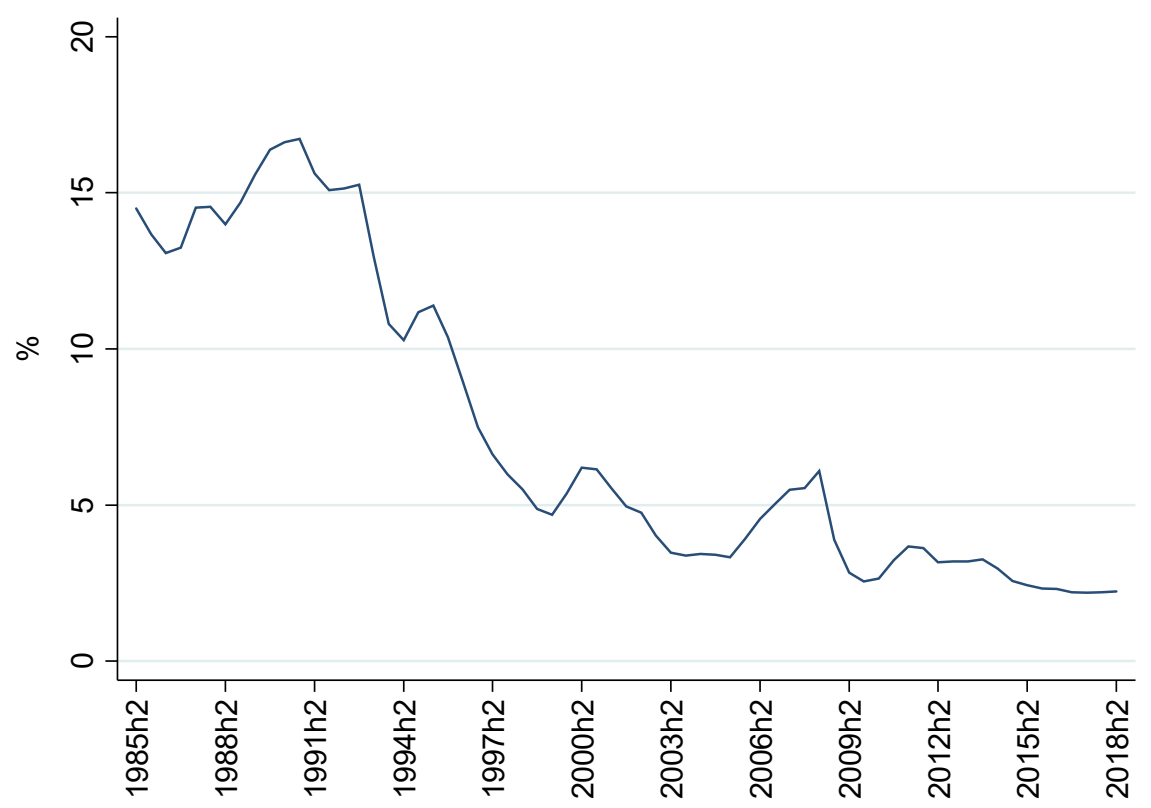


A.5 Average percentage of population between 30 and 54 years

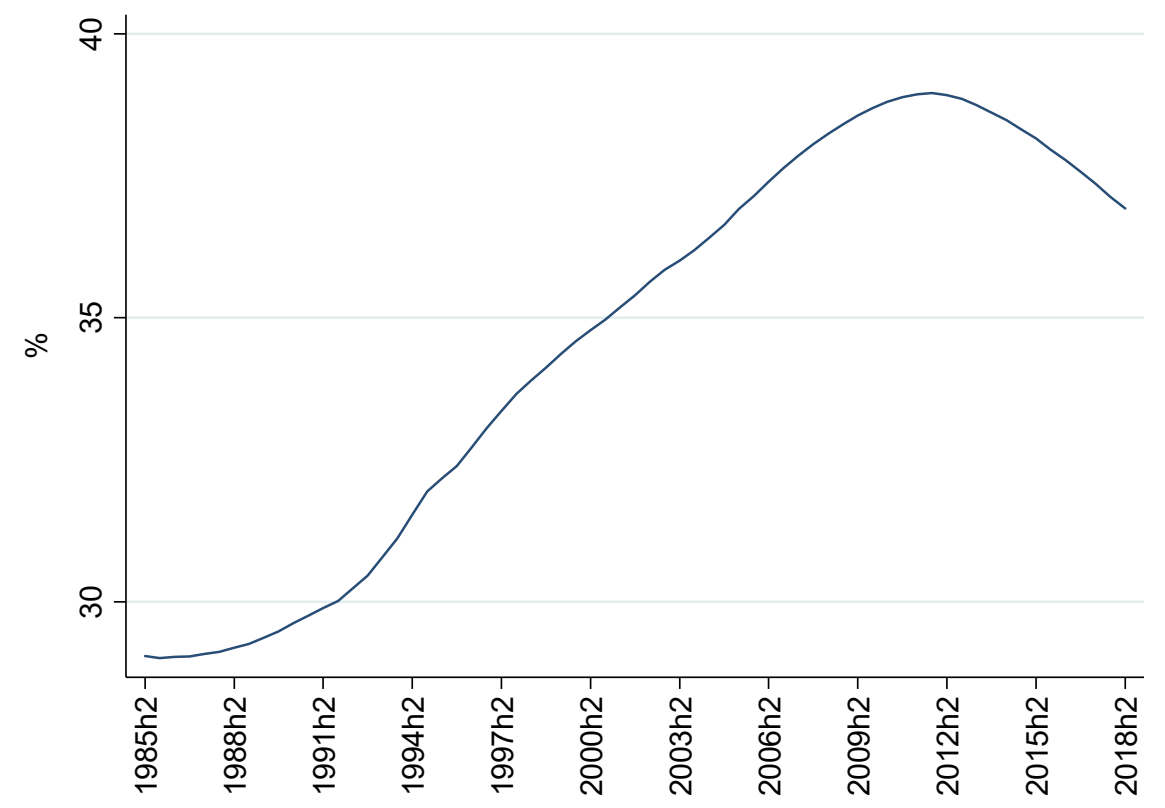

A.6 Average housing credit to annual income

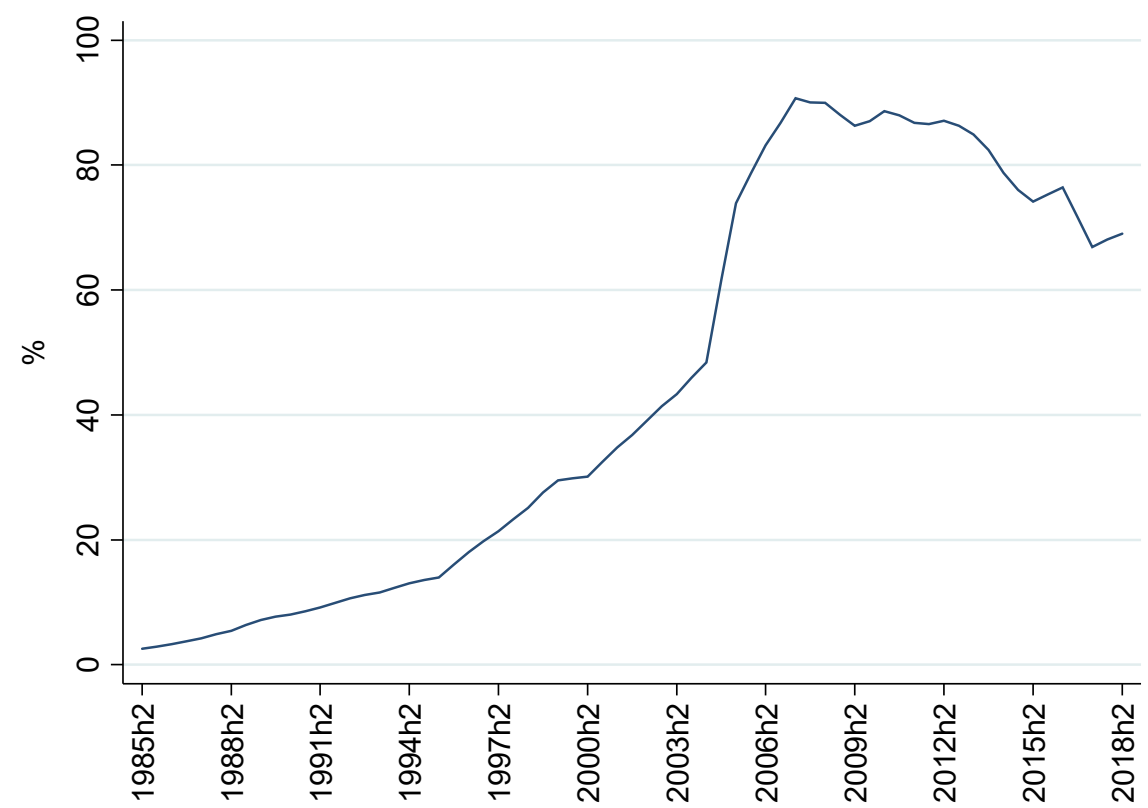


A.7 Average housing stock per capita

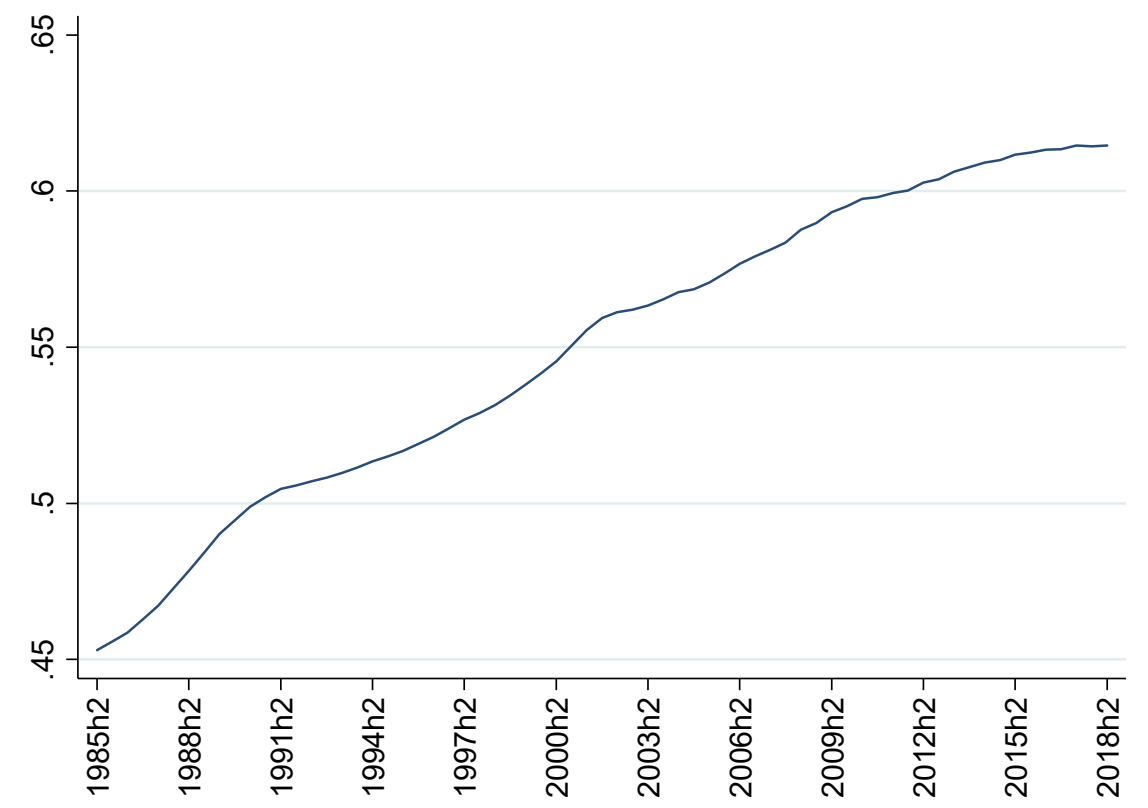

A.8 Real construction (residential and non-residential) costs

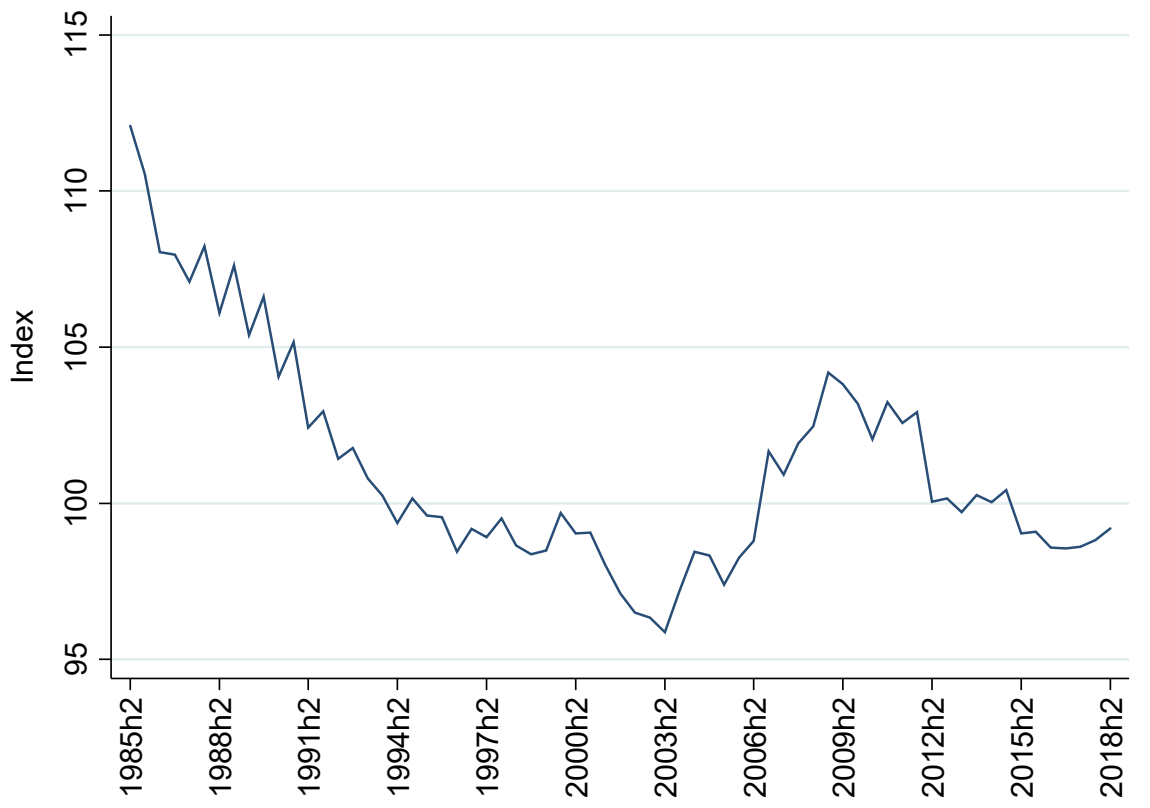




\title{
BANCO DE ESPAÑA PUBLICATIONS
}

\author{
WORKING PAPERS
}

1840 ALESSIO MORO and OMAR RACHEDI: The changing structure of government consumption spending.

1841 GERGELY GANICS, ATSUSHI INOUE and BARBARA ROSSI: Confidence intervals for bias and size distortion in IV and local projections - IV models.

1842 MARÍA GIL, JAVIER J. PÉREZ, A. JESÚS SÁNCHEZ and ALBERTO URTASUN: Nowcasting private consumption: traditional indicators, uncertainty measures, credit cards and some internet data.

1843 MATÍAS LAMAS and JAVIER MENCÍA: What drives sovereign debt portfolios of banks in a crisis context?

1844 MIGUEL ALMUNIA, POL ANTRÀS, DAVID LÓPEZ-RODRÍGUEZ and EDUARDO MORALES: Venting out: exports during a domestic slump.

1845 LUCA FORNARO and FEDERICA ROMEI: The paradox of global thrift.

1846 JUAN S. MORA-SANGUINETTI and MARTA MARTÍNEZ-MATUTE: An economic analysis of court fees: evidence from the Spanish civil jurisdiction.

1847 MIKEL BEDAYO, ÁNGEL ESTRADA and JESÚS SAURINA: Bank capital, lending booms, and busts. Evidence from Spain in the last 150 years.

1848 DANIEL DEJUÁN and CORINNA GHIRELLI: Policy uncertainty and investment in Spain.

1849 CRISTINA BARCELÓ and ERNESTO VILLANUEVA: The risk of job loss, household formation and housing demand: evidence from differences in severance payments.

1850 FEDERICO TAGLIATI: Welfare effects of an in-kind transfer program: evidence from Mexico.

1851 ÓSCAR ARCE, GALO NUÑO, DOMINIK THALER and CARLOS THOMAS: A large central bank balance sheet? Floor vs corridor systems in a New Keynesian environment.

1901 EDUARDO GUTIÉRREZ and ENRIQUE MORAL-BENITO: Trade and credit: revisiting the evidence.

1902 LAURENT CAVENAILE and PAU ROLDAN: Advertising, innovation and economic growth.

1903 DESISLAVA C. ANDREEVA and MIGUEL GARCÍA-POSADA: The impact of the ECB's targeted long-term refinancing operations on banks' lending policies: the role of competition.

1904 ANDREA ALBANESE, CORINNA GHIRELLI and MATTEO PICCHIO: Timed to say goodbye: does unemployment benefit eligibility affect worker layoffs?

1905 CORINNA GHIRELLI, MARÍA GIL, JAVIER J. PÉREZ and ALBERTO URTASUN: Measuring economic and economic policy uncertainty, and their macroeconomic effects: the case of Spain.

1906 CORINNA GHIRELLI, JAVIER J. PÉREZ and ALBERTO URTASUN: A new economic policy uncertainty index for Spain.

1907 ESTEBAN GARCÍA-MIRALLES, NEZIH GUNER and ROBERTO RAMOS: The Spanish personal income tax: facts and parametric estimates.

1908 SERGIO MAYORDOMO and OMAR RACHEDI: The China syndrome affects banks: the credit supply channel of foreign import competition.

1909 MÓNICA CORREA-LÓPEZ, MATÍAS PACCE and KATHI SCHLEPPER: Exploring trend inflation dynamics in Euro Area countries.

1910 JAMES COSTAIN, ANTON NAKOV and BORJA PETIT: Monetary policy implications of state-dependent prices and wages.

1911 JAMES CLOYNE, CLODOMIRO FERREIRA, MAREN FROEMEL and PAOLO SURICO: Monetary policy, corporate finance and investment.

1912 CHRISTIAN CASTRO and JORGE E. GALÁN: Drivers of productivity in the Spanish banking sector: recent evidence.

1913 SUSANA PÁRRAGA RODRÍGUEZ: The effects of pension-related policies on household spending.

1914 MÁXIMO CAMACHO, MARÍA DOLORES GADEA and ANA GÓMEZ LOSCOS: A new approach to dating the reference cycle.

1915 LAURA HOSPIDO, LUC LAEVEN and ANA LAMO: The gender promotion gap: evidence from Central Banking.

1916 PABLO AGUILAR, STEPHAN FAHR, EDDIE GERBA and SAMUEL HURTADO: Quest for robust optimal macroprudential policy.

1917 CARMEN BROTO and MATÍAS LAMAS: Is market liquidity less resilient after the financial crisis? Evidence for US treasuries.

1918 LAURA HOSPIDO and CARLOS SANZ: Gender Gaps in the Evaluation of Research: Evidence from Submissions to Economics Conferences.

1919 SAKI BIGIO, GALO NUÑO and JUAN PASSADORE: A framework for debt-maturity management.

1920 LUIS J. ÁLVAREZ, MARÍA DOLORES GADEA and ANA GÓMEZ-LOSCOS: Inflation interdependence in advanced economies. 
1921 DIEGO BODAS, JUAN R. GARCÍA LÓPEZ, JUAN MURILLO ARIAS, MATÍAS J. PACCE, TOMASA RODRIGO LÓPEZ, JUAN DE DIOS ROMERO PALOP, PEP RUIZ DE AGUIRRE, CAMILO A. ULLOA and HERIBERT VALERO LAPAZ: Measuring retail trade using card transactional data.

1922 MARIO ALLOZA and CARLOS SANZ: Jobs multipliers: evidence from a large fiscal stimulus in Spain.

1923 KATARZYNA BUDNIK, MASSIMILIANO AFFINITO, GAIA BARBIC, SAIFFEDINE BEN HADJ, ÉDOUARD CHRÉTIEN, HANS DEWACHTER, CLARA ISABEL GONZÁLEZ, JENNY HU, LAURI JANTUNEN, RAMONA JIMBOREAN, OTSO MANNINEN, RICARDO MARTINHO, JAVIER MENCÍA, ELENA MOUSARRI, LAURYNAS NARUŠEVIČIUS, GIULIO NICOLETTI, MICHAEL O'GRADY, SELCUK OZSAHIN, ANA REGINA PEREIRA, JAIRO RIVERA-ROZO, CONSTANTINOS TRIKOUPIS, FABRIZIO VENDITTI and SOFÍA VELASCO: The benefits and costs of adjusting bank capitalisation: evidence from Euro Area countries.

1924 MIGUEL ALMUNIA and DAVID LÓPEZ-RODRÍGUEZ: The elasticity of taxable income in Spain: 1999-2014.

1925 DANILO LEIVA-LEON and LORENZO DUCTOR: Fluctuations in global macro volatility.

1926 JEF BOECKX, MAARTEN DOSSCHE, ALESSANDRO GALESI, BORIS HOFMANN and GERT PEERSMAN: Do SVARs with sign restrictions not identify unconventional monetary policy shocks?

1927 DANIEL DEJUÁN and JUAN S. MORA-SANGUINETTI: Quality of enforcement and investment decisions. Firm-level evidence from Spain.

1928 MARIO IZQUIERDO, ENRIQUE MORAL-BENITO and ELVIRA PRADES: Propagation of sector-specific shocks within Spain and other countries.

1929 MIGUEL CASARES, LUCA DEIDDA and JOSÉ E. GALDÓN-SÁNCHEZ: On financial frictions and firm market power.

1930 MICHAEL FUNKE, DANILO LEIVA-LEON and ANDREW TSANG: Mapping China's time-varying house price landscape.

1931 JORGE E. GALÁN and MATÍAS LAMAS: Beyond the LTV ratio: new macroprudential lessons from Spain.

1932 JACOPO TIMINI: Staying dry on Spanish wine: the rejection of the 1905 Spanish-Italian trade agreement.

1933 TERESA SASTRE and LAURA HERAS RECUERO: Domestic and foreign investment in advanced economies. The role of industry integration.

1934 DANILO LEIVA-LEON, JAIME MARTÍNEZ-MARTÍN and EVA ORTEGA: Exchange rate shocks and inflation comovement in the euro area.

1935 FEDERICO TAGLIATI: Child labor under cash and in-kind transfers: evidence from rural Mexico.

1936 ALBERTO FUERTES: External adjustment with a common currency: the case of the euro area.

1937 LAURA HERAS RECUERO and ROBERTO PASCUAL GONZÁLEZ: Economic growth, institutional quality and financial development in middle-income countries.

1938 SILVIA ALBRIZIO, SANGYUP CHOI, DAVIDE FURCERI and CHANSIK YOON: International Bank Lending Channel of Monetary Policy.

1939 MAR DELGADO-TÉLLEZ, ENRIQUE MORAL-BENITO and JAVIER J. PÉREZ: Outsourcing and public expenditure: an aggregate perspective with regional data.

1940 MYROSLAV PIDKUYKO: Heterogeneous spillovers of housing credit policy.

1941 LAURA ÁLVAREZ ROMÁN and MIGUEL GARCÍA-POSADA GÓMEZ: Modelling regional housing prices in Spain.

\section{BANCODEESPAÑA} Eurosistema
Unidad de Servicios Auxiliares

Alcalá, 48 - 28014 Madrid

E-mail: publicaciones@bde.es www.bde.es 